\title{
A diverse Pleistocene marsupial trackway assemblage from the Victorian Volcanic Plains, Australia
}

\author{
Stephen P. Carey ${ }^{\mathrm{a}, *}$, Aaron B. Camens ${ }^{\mathrm{b}, * *}$, Matthew L. Cupper ${ }^{\mathrm{c}}$, Rainer Grün ${ }^{\mathrm{d}}$, John C. Hellstrom ${ }^{\mathrm{c}}$, \\ Stafford W. McKnight ${ }^{a}$, Iain Mclennan ${ }^{a}$, David A. Pickering ${ }^{\mathrm{e}}$, Peter Trusler ${ }^{\mathrm{f}}$, Maxime Aubert ${ }^{\mathrm{d}}$ \\ ${ }^{a}$ Centre for Environmental Management, School of Science and Engineering, University of Ballarat, PO Box 663, Ballarat, Victoria 3353, Australia \\ ${ }^{\mathrm{b}}$ Department of Earth and Environmental Sciences, University of Adelaide, South Australia 5005, Australia \\ ${ }^{\mathrm{c}}$ School of Earth Sciences, The University of Melbourne, Victoria 3010, Australia \\ ${ }^{\mathrm{d}}$ Research School of Earth Sciences, The Australian National University, Canberra ACT 0200, Australia

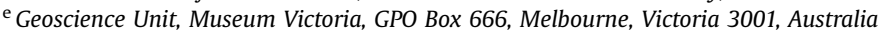 \\ ${ }^{\mathrm{f}}$ School of Earth Sciences, Monash University, Clayton, Victoria 3800, Australia
}

\section{A R T I C L E I N F O}

\section{Article history:}

Received 18 August 2010

Received in revised form

23 November 2010

Accepted 24 November 2010

Available online 1 February 2011

\section{Keywords:}

Diprotodontid

Ichnology

Trackways

Gait

Pleistocene

Victoria

\begin{abstract}
A B S T R A C T
A diverse assemblage of late Pleistocene marsupial trackways on a lake bed in south-western Victoria provides the first information relating to the gaits and morphology of several megafaunal species, and represents the most speciose and best preserved megafaunal footprint site in Australia. The 60-110 ka volcaniclastic lacustrine sedimentary rocks preserve trackways of the diprotodontid Diprotodon optatum, a macropodid (probably Protemnodon sp.) and a large vombatid (perhaps Ramsayia magna or 'Phascolomys' medius) and possible prints of the marsupial lion, Thylacoleo carnifex. The footprints were imprinted within a short time period, demonstrating the association of the taxa present, rather than the time-averaged accumulations usually observed in skeletal fossil deposits. Individual manus and pes prints are distinguishable in some trackways, and in many cases some digital pad morphology is also present. Several parameters traditionally used to differentiate ichnotaxa, including trackway gauge and the degree of print in-turning relative to the midline, are shown to be subject to significant intraspecific variation in marsupials. Sexual dimorphism in the trackway proportions of Diprotodon, and its potential for occurrence in all large bodied, quadrupedal marsupials, is identified here for the first time.
\end{abstract}

(ㄷ) 2010 Elsevier Ltd. All rights reserved.

\section{Introduction}

Fossil trackways commonly preserve characteristics of organisms not available from their skeletal fossil record. Trackways can provide insight into the biomechanics and palaeobiology of a species not evident from the skeleton (Lockley, 1998). It may be possible to determine the gait, foot morphology, size and speed of travel of individuals, as well as factors of wider ecological importance, such as community composition and species diversity (Camens and Wells, 2009). In addition, the rheology of the sediments preserving the prints can reveal aspects of the environment at the time of deposition (Allen, 1989, 1997).

\footnotetext{
* Corresponding author. Tel.: +61 35327 9268; fax: +61 353279144.

** Corresponding author. Tel.: +61 431633096.

E-mail addresses: s.carey@ballarat.edu.au (S.P. Carey), aaron.camens@adelaide. edu.au (A.B. Camens).
}

Mammalian trackways have been widely studied in many parts of the world (e.g. Leakey and Hay, 1979; Belperio and Fotheringham, 1990; Cohen et al., 1993; Lea, 1996; Allen, 1997; Lockley et al., 1999; Ataabadi and Sarjeant, 2000; Mietto et al., 2003; Triggs, 2004; Webb et al., 2006), as have those of dinosaurs (e.g. Alexander, 1976; Thulborn and Wade, 1984; Lockley, 1986a; Thulborn, 1989, 1990; Farlow et al., 2000). However, mammalian fossil trackways are rare in Australia, the five described sites being restricted to the Pliocene and Pleistocene. These sites include late Pleistocene human footprints at the Willandra Lakes in New South Wales (Webb et al., 2006) and Holocene human footprints at Clare Bay in South Australia (Belperio and Fotheringham, 1990). Marsupial traces include macropodid (possibly Protemnodon) footprints, from near Clare Bay (Belperio and Fotheringham, 1990), Pleistocene Diprotodon footprints at Lake Callabonna (Tedford, 1973; Wells and Tedford, 1995) and Pliocene Euowenia grata footprints from the Warburton River (Camens and Wells, 2009), all in South Australia, and kangaroo tracks from the Willandra Lakes, New South Wales (Webb et al., 2006). The site described below thus contains more 
fossil marsupial footprints than have previously been described for the whole of the Australian Quaternary.

Most fossil mammal trackways previously described were created by hooved ungulates (e.g. Laporte and Behrensmeyer, 1980; Loope, 1986; Allen, 1989, 1997; Lea, 1996; Lockley et al., 1999; Fornós et al., 2002), their hard hooves having the potential to leave tracks both deeper and in a wider range of substrates than the soft-footed marsupials. This may help to explain the paucity of fossil mammal footprints in Australia, as the soft feet of all members of the Australian fauna would leave shallower tracks that are less clearly defined and less likely to be preserved.

Here we describe the most diverse assemblage of marsupial trackways yet discovered in Australia. Their superb preservation allows us to determine the trackmakers at familial, generic or even species level. In the case of the most spectacular trackway, we are able to estimate the animal's speed and suggest its sex. Our geological analysis provides temporal context for the trackways together with an understanding of the environment in which they were active. Accordingly, we aim to shine a light on the late Pleistocene ecosystem of the fertile and well watered volcanic plains of south-eastern Australia.

\section{Regional setting}

The megafaunal marsupial trackways occur on a lake margin within the Victorian Volcanic Plains (VVP) of south-eastern Australia (Fig. 1). Details of the location are not provided here because a plan of management to protect the locality from human interference and the elements has not yet been developed. Those details are, however, held at Museum Victoria, Melbourne, in the documentation of six moulds and casts taken from the trackways (MV P230853 to P230858). The unnamed lithostratigraphic unit containing the trackways is part of a complex of lacustrine and associated aeolian deposits surrounded by the Newer Volcanic Group, a suite of Miocene-Holocene basaltic lavas and pyroclastics that extends from central Victoria westward to the south-eastern extremity of South Australia (VandenBerg, 2009). Locally known for some time as "dinosaur footprints", the trackways were under water in the recent past but, with continuing dry years, are now exposed.

\section{Materials and methods}

\subsection{Trackway mapping}

The position, length and width of each footprint were recorded on a gridded plan using tape measure and compass. A more or less continuous series of footprints made by one individual as it traversed the site was defined as a trackway. For the diprotodontid trackways the length, width and depth of each print were measured and its distance from an arbitrary datum recorded. Stride length was measured as the distance between corresponding points on successive footprints. Trackway width was measured as the shortest distance from a line drawn between the median points of two consecutive footprints on one side of the trackway to the median point of a footprint on the other side. Pace angulation was measured as the angle formed between two consecutive pes prints on one side of the trackway and the intervening pes print on the other side. Where possible, individual manus and pes imprints were identified. Manus and pes prints were distinguished both by their position (diprotodontid manus prints are generally just in front of the pes prints) and their shape (diprotodontid manus prints are semicircular while the pes prints are reniform). The mapping data were plotted with the use of GIS software, MapInfo. Each trackway was photographed from a ladder and a photomosaic assembled. Consecutive photos overlapped by at least $20 \%$, and a measuring tape

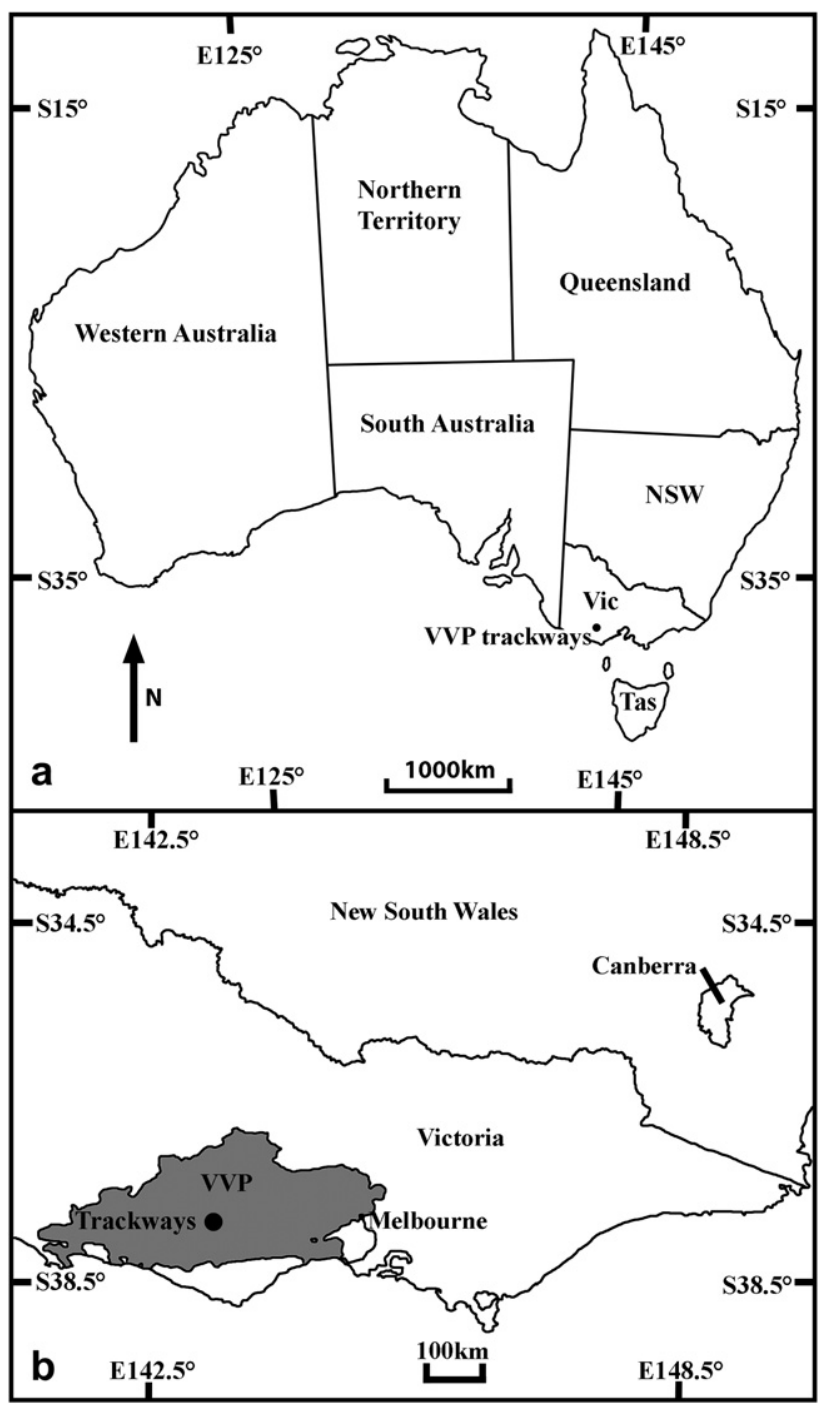

Fig. 1. Maps showing the location of the trackways: in Australia (a), internal lines represent state boundaries; and the location of the trackways within the Victorian Volcanic Plains (b) (shaded area).

was placed alongside the trackways to help detect and reduce parallax effects. Measurements taken from the photomosiacs were also checked against measurements taken in the field for consistency. Scale plans were then constructed to facilitate spatial analysis.

\subsection{Trackway analysis}

Walking speed was estimated by application of the formula of Alexander (1976):

$\mathrm{V}=0.25 \mathrm{~g}^{0.5} \mathrm{SL}^{1.67} \mathrm{~h}^{-1.17}$

where $\mathrm{V}$ is the velocity in $\mathrm{ms}^{-1}$, $\mathrm{g}$ is the acceleration due to gravity $\left(9.8 \mathrm{~ms}^{-2}\right)$, SL refers to stride length $(\mathrm{m})$ and $\mathrm{h}$ is the height of the hip above the ground $(\mathrm{m})$. The gleno-acetabular distance (the trunk length, measured from scapula-humeral articulation to acetabulum) was used to help identify trackmakers, and was calculated using Haubold's formula, $\mathrm{L}=3 / 4$ stride + distance between footprints of manus and pes, quoted in Stossel (1995, p. 411).

The two diprotodontid genera known from late Pleistocene deposits in south-eastern Australia are Diprotodon and Zygomaturus. Each genus is generally considered to be represented by a single 
species in the late Pleistocene, D. optatum and Z. trilobus (Murray, 1991; Long et al., 2002; Price, 2008). We made the initial assumption that the animal responsible for the diprotodontid trackway could have been either Diprotodon optatum or Zygomaturus trilobus. The hip height for the trackmaker was calculated from the ratio of the trackway width to the hip height, as measured from the mounted skeletons of the two species at the South Australian Museum (SAM; Adelaide, South Australia) and the Queen Victoria Museum and Art Gallery (QVMAG; Launceston, Tasmania) respectively. We acknowledge that these reconstructions represent a theoretical arrangement of the limbs. As demonstrated by the ratios determined below, skeletal characters such as the width of the pelvis reveal that the trackway width of Z. trilobus is likely to be proportionally greater than that of D. optatum.

For the trackways identified as being made by a large extinct wombat (either Ramsayia or 'Phascolomys'), the speed of the trackway maker was not calculated, as no complete skeleton is known to allow measurement of the relevant body proportions. Speed could not be estimated from the macropodid trackways as Alexander's (1976) formula does not apply to a hopping gait.

To aid in identification of the maker of the small-quadruped trackways, tracks of the extant common wombat (Vombatus ursinus) were examined. This involved spreading sand in a wombat pen at Cleland Wildlife Park, Crafers, South Australia, then both photographing and measuring the tracks made in the sand by an adult female wombat as it moved over the sand. Tracks were observed and measured for both a trotting and a walking gait.

\subsection{Skeletal fossils}

Skeletal fossils were recovered from two places at the trackways locality (Fig. 2). Several specimens and a sample of the matrix from skeletal accumulation 2 were used to assist in determining the age of the trackways.

\subsection{Geochronology}

Three techniques, optically stimulated luminescence (OSL), combined uranium series/electron spin resonance (U-series/ESR), and uranium/thorium (U-Th) analysis, were applied to constrain the age of the trackways and the associated skeletal fossils.

1. OSL dating was used to estimate the depositional ages of two samples of sediment. One sample was collected from the volcaniclastic sandstone hosting the trackways, and came from a few centimetres below the trackway surface, near the diprotodontid trackway, T1. The other sample was from the muddy sand that formed the matrix to the fossils of skeletal accumulation 2 (Fig. 2). Samples were collected by driving $40 \mathrm{~mm}$ diameter stainless steel tubes into cleaned sections.

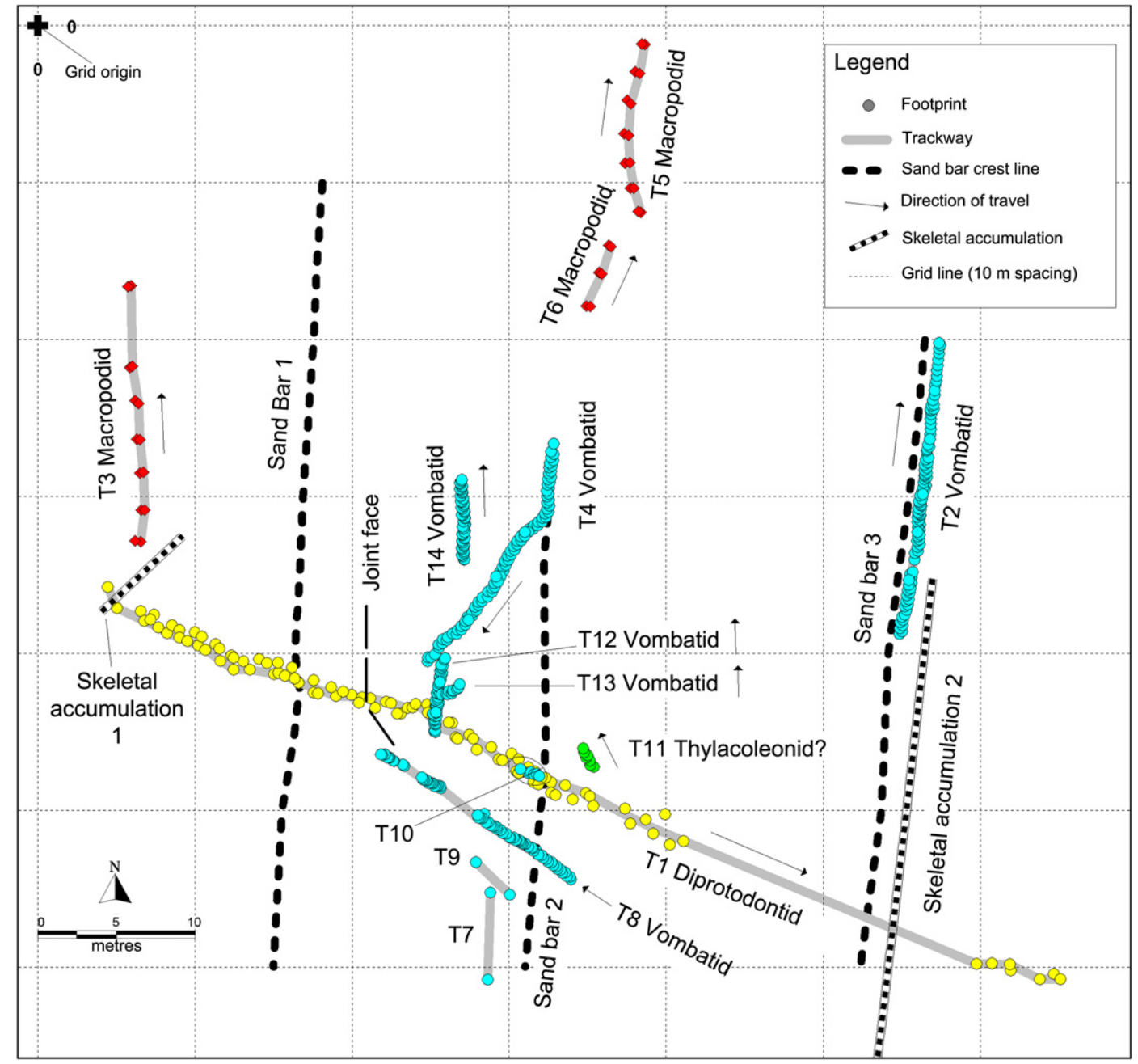

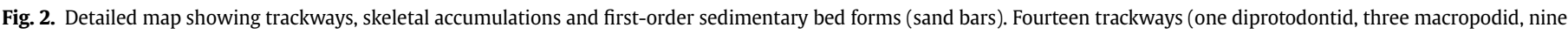
vombatid and one possible thylacoleonid) are represented. A second diprotodontid trackway occurs about $30 \mathrm{~m}$ north-west of the origin. Map courtesy of M. Gibson. 
The samples were processed under subdued red light, with the 180-212 $\mu \mathrm{m}$ quartz fraction extracted for dating using standard procedures (e.g. Galbraith et al., 1999). A single-aliquot regenerativedose protocol was used to calculate equivalent doses (Murray and Roberts, 1998; Galbraith et al., 1999; Murray and Wintle, 2000) following the analytical procedures described in Quigley et al.(2006).

2. Combined U-series/ESR analysis was applied to marsupial (macropodid) teeth collected from skeletal accumulation 2 (Fig. 2). The dating procedures followed those routinely applied in the Australian National University ESR dating laboratory. From each tooth, an enamel fragment with attached dentine was removed and analysed for uranium and thorium using laser ablation ICP-MS (Eggins et al., 2003, 2005). The sediments were analysed for $\mathrm{U}$, Th, and $\mathrm{K}$ by solution ICP-MS (Genalysis, Perth). For ESR dose analysis, the enamel was powdered and successively irradiated in 12 steps to $716 \mathrm{~Gy}$. Radiation doses were monitored with alanine dosimeters and evaluated against a calibrated dosimeter set (A. Wieser, Messtechnik, München). Dose values were obtained by fitting the natural spectrum back into the irradiated ones (Grün, 2002).

Chemical data were converted into dose rates using the conversion tables of Adamiec and Aitken (1998). For the calculation of the internal dose rate values, beta attenuation values of Marsh (1999) and an alpha efficiency of $0.13 \pm 0.02$ (Grün and Katzenberger-Apel, 1994) were used. The beta dose rate was derived from the chemical analysis of sediment samples that were attached to the teeth. For the calculation of the external gamma dose rate, we used the following calculations: (i) Around 50\% of the gamma dose rate was generated by the $5 \mathrm{~cm}$ of matter surrounding the sample (Aitken et al., 1985). We regard the sediment samples adhering to the teeth as being representative for this near-field. (ii) The other $50 \%$ was derived from the in situ gamma spectrometric measurements. All analyses assumed the present-day water content of $27.5 \pm 5 \%$ and a depth of $15 \pm 5 \mathrm{~cm}$ for the cosmic dose rate calculations (Prescott and Hutton, 1988, 1994). Age calculations were carried out with the ESR-DATA program (Grün, 2009a).

3. The U-Th technique was used to determine the age of the dolomitic limestone that overlies the trackways-bearing volcaniclastic sandstone. Slabbed sections of the limestone were carefully examined to find the least permeable material possible, to reduce the likelihood of sampling post-depositional uranium mobility. Within this impermeable material, the purest available carbonate was chosen on the basis of colour. Three sub-samples of $\sim 10 \mathrm{mg}$ were taken for $\mathrm{U}-\mathrm{Th}$ analysis, following the procedure of Hellstrom (2003). Samples were dissolved in $\mathrm{HNO}_{3}$ and spiked with a ${ }^{229} \mathrm{Th}-{ }^{233} \mathrm{U}$ mixed tracer, followed by chemical extraction of the $U$ and Th fraction using Eichrom TRU-Spec ion exchange resin. Isotopic analysis was undertaken using a $\mathrm{Nu}$ Instruments Nu Plasma multi-collector ICP-MS, allowing simultaneous measurement of all required isotope ratios. Corrected ages were calculated assuming a broadly bulk crustal composition for the detrital Th component of $\left[{ }^{230} \mathrm{Th} /{ }^{232} \mathrm{Th}\right]_{\mathrm{i}}=1.0 \pm 0.5$, following standard practice (Richards and Dorale, 2003).

\section{Results}

\subsection{Geological description}

The trackways occur in volcaniclastic rocks, while associated vertebrate skeletal fossils were found in pockets of sandy mud and ferruginised sandstone that exist within the volcaniclastics. The thickness of the exposed strata is less than $0.5 \mathrm{~m}$. Two contrasting units are present, the lower one being volcaniclastic and the upper one a micritic carbonate. Eight short cores (8-29 cm long) were extracted from the lower unit within the confines of the grid.

\subsubsection{Lower unit}

The lower (volcaniclastic) unit contains the trackways on its upper surface as well as the fossil skeletal remains. It is exposed across much of the mapping grid, as well as for a few metres east of the grid, intermittently for tens of metres to the west and south, and at about $200 \mathrm{~m}$ to the north. It is at least $30 \mathrm{~cm}$ thick. The volcaniclastics are distinctly stratified, to form very thin beds which are internally laminated or cross-laminated. Many of the strata are clinoformal, with primary dips (always to the east) typically around $10^{\circ}$ and ranging up to $22^{\circ}$. Bedding surfaces are planar or rippled (see below for bed forms and associated features). Millimetre-scale cut-and-fill features are common, in addition to larger current scours associated with the sand bars present. One portion of the exposure displays convolute bedding which may be track-related. The rock is highly porous and weakly to very friable, except for the top few millimetres which are strongly cemented. Its colour varies between very dark grey ( 7.5 YR 3/1, dry) and dark yellowish brown (10 YR 4/4). Texturally, the lower unit includes a mix of very fine- to fine-grained, medium-grained, coarse-grained and pebble/granule coarse-grained sandstone. Its mineralogy is dominated by volcanic glass, quartz, plagioclase and opaque nodules (iron oxyhydroxide), with subordinate to trace amounts of augite, olivine, crystalline basaltic lithics, and reworked calcareous fossils and fossil fragments (including foraminifers filled with reddish clay) (Fig. 3). Semiquantitative XRD shows the presence of smectite with an abundance in the range $2-8 \%$ (Fig. 4 ). Some of the surface is covered by a crust of calcite $<1-3 \mathrm{~mm}$ thick. Calcitic cement occludes the porosity in the volcaniclastics immediately below the crust as well as across a broad portion of the exposure to a depth of a centimetre where the calcite disappears.

Two orders of bed forms are present. The larger, first-order bed forms are sand bars, oriented north-south, which exercise a clear control over the character of some trackways. They are tens of metres long and 10-15 m wide, have a relief of $10-15 \mathrm{~cm}$, and are subparallel to the topographic contours of the slightly more elevated area to the west. Three sand bars can be distinguished within and to the south of the gridded area (Fig. 2), but die out near the grid's northern margin. Eastward, each successive sand bar is at a lower elevation than the previous one, forming a step-like pattern. The bars are asymmetrical in east-west profile, being near-horizontal west of the brink line but sloping at up to $8^{\circ}$ on the east. The brink lines of the bars plunge very gently to the south. Thin to very thin beds (clinoforms) dip easterly off the sand bars, with the dips being primary. Second-order bed forms, in the form of ripples, are abundant upon portions of both the crests and the upper slopes of the sand bars. Other parts of the exposure are characterised by planar surfaces, including parts of the crests and the lower slopes of the sand bars and adjacent troughs. Ripples include symmetrical, straight-crested, sinuous-crested and linguoid variants (Fig. 5). The predominant direction of wave movement, as determined from the ripples, was toward the west (Fig. 6). Erosional scours are abundant along the eastern sides of the sand bars (Fig. 5) and, in some cases, are responsible for expunging footprints. Oriented roughly east-west, with the headward limits to the west, they vary from tens of centimetres to about $2 \mathrm{~m}$ in length, and a few to a few tens of centimetres in breadth. Their vertical relief is a maximum of $3-4 \mathrm{~cm}$, with the margins being near-vertical to slightly overhanging. Some scours pass down slope into small deltas, $30-70 \mathrm{~cm}$ across and $1-<2 \mathrm{~m}$ long, that are situated in the adjacent trough. One especially large scour, traceable for $15 \mathrm{~m}$ and $5 \mathrm{~m}$ wide at the northern end of the western sand bar, 


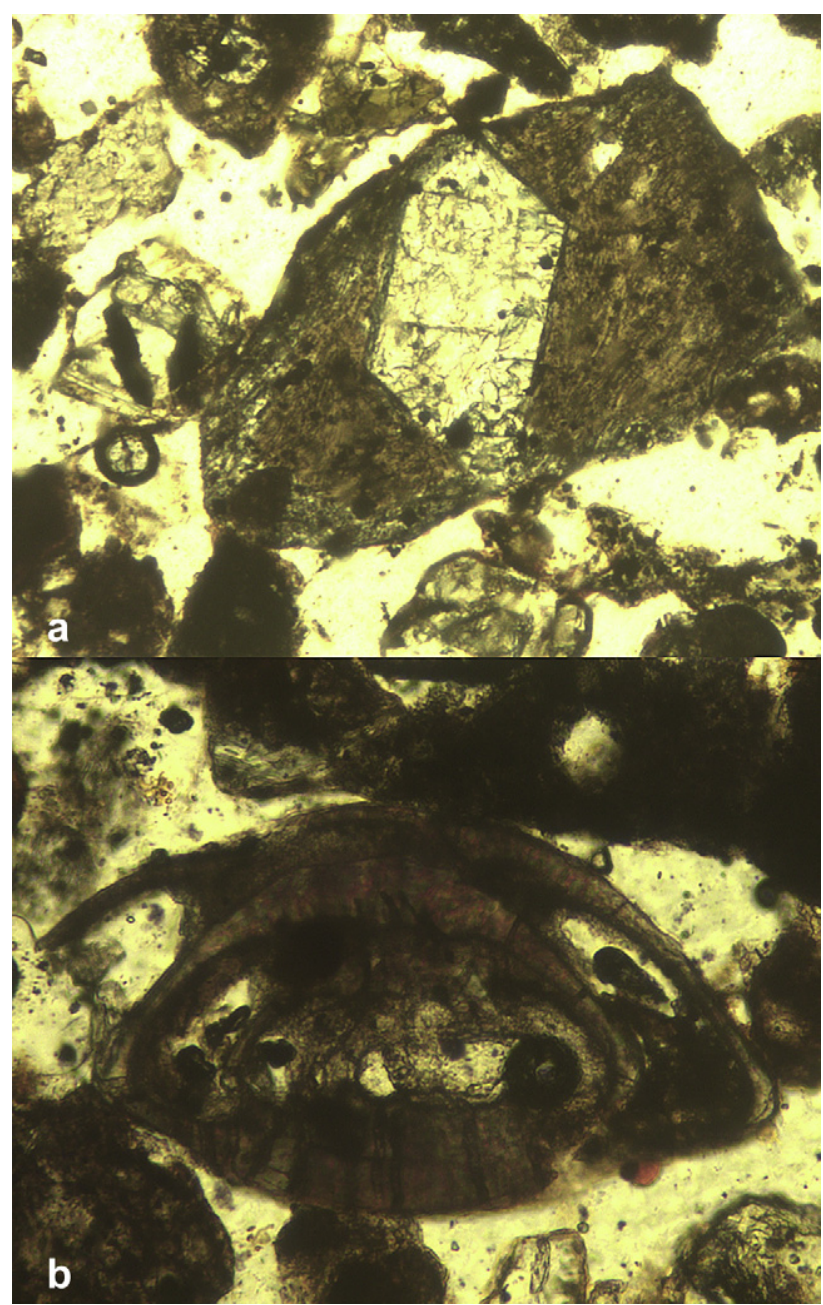

Fig. 3. Microscopic features of trackway-bearing volcaniclastic sandstone. Glassy volcanic fragment with pyroxene crystal, grain $\sim 0.7 \mathrm{~mm}$ long, plane polarised light ( $\mathrm{ppl}$ ) (a); reworked foraminifer, probably from Gellibrand Marl, $\sim 0.3 \mathrm{~mm}$ wide, $\mathrm{ppl}$ (b).

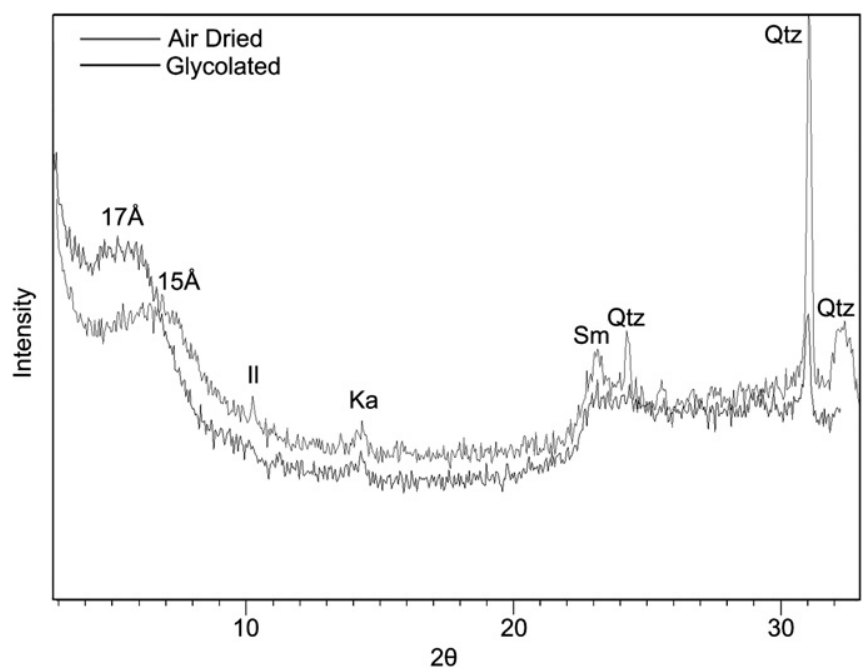

Fig. 4. X-ray diffractograms (air-dried and glycolated) for sample derived from trackways-bearing volcaniclastic sandstone. Smectite presence confirmed by shift of $15 \AA$ peak on air-dried trace to $17 \AA$ peak on glycolated trace. Abbreviations on peaks: Il-illite; Ka-kaolinite; Qtz-quartz; Sm-smectite. transects the sand bar in an easterly direction before heading south-east. All but the largest scours were fed by pore water seeping from the sand bars. Localised soft-sediment deformation, defined by distorted stratification, may be due to animal trampling and later erosion of the tracking surface (Fig. 7). Centimetre-scale invertebrate burrows and the moulds of probable plant stems (Fig. 7) are locally abundant.

The two skeletal accumulations (Fig. 2) are within the volcaniclastic sandstone and exposed at its surface. The upper part of both is an unconsolidated sandy mud with easily extracted fossil bones and teeth. The lower parts of both are cemented to form volcaniclastic sandstone with skeletal fossils embedded. Skeletal accumulation 1 transects the proximal end of diprotodontid trackway $\mathrm{T} 1$ and is elongate in a NE-SW direction. Despite its trench-like character at the surface, it lacks a distinct, channelised base. Instead, its lower part is continuous with the volcaniclastic host of T1. Skeletal accumulation 2 is at the toe of the east-dipping slope of sand bar 3, just below T2, which occurs along the sand bar's slope. It is elongate in a $\mathrm{N}-\mathrm{S}$ direction and appears to have formed in the trough adjacent to the sand bar. Again, there is no obvious boundary between the base of the skeletal accumulation and the adjacent volcaniclastic sandstone.

\subsubsection{Upper unit}

The upper unit is a micritic carbonate that overlies the lower unit, except where it is eroded to expose the trackways. It has been stripped entirely from within the grid, and occurs within a few metres of the east, north and west margins of the grid. Outcrop of the micritic carbonate can be traced about $10 \mathrm{~m}$ east of the grid limits, tens of metres west, and several hundred metres north and southwest. The base of the upper unit is slightly irregular. Ten to $15 \mathrm{~cm}$ thick, it lacks obvious depositional structures but has many fine fractures that make it rubbly and define centimetre-scale blocks. While generally a dolomitic lime mudstone with a quartz sand component (10-20\%) and numerous fine root casts, it is locally heterolithic, with a framework of volcaniclastic pebbles and sand and a matrix of carbonate (calcite and dolomite). It has little porosity, as interparticulate, intraparticulate and fine fracture porosity is occluded by micritic carbonate. Exposed surfaces are very pale brown (10 YR 8/2, dry) while slabbed surfaces are greyish brown (10 YR 5/5, dry). Semi-quantitative XRD shows that the carbonate unit is a dolomitic limestone (Fig. 8). The ratio, dolomite:calcite, varies between $1: 1$ and $1: 4$ in three samples. The calcite is magnesian and the dolomite is non-stoichiometric, with a ferroan component.

\subsection{Structural features}

Semi-regular vertical jointing is a character of the lower (volcaniclastic) unit. Joints extend to only a very shallow depth, apparently $<0.5 \mathrm{~m}$. Where the volcaniclastic sandstone is more strongly consolidated, jointing is mostly oriented north-south, with a spacing of $0.3-8 \mathrm{~m}$, whereas the less strongly consolidated sandstone exhibits fracturing that is very variable in orientation and whose spacing is in the range $0.05-1 \mathrm{~m}$. In the most significant example, a joint that intersects the major diprotodontid trackway (T1) affects the uppermost $220 \mathrm{~mm}$ of the exposure, but has not propagated more deeply. The unexplained removal at some time in the past of a wedge-shaped block of volcaniclastics from immediately west of this joint has exposed (i) compactional depression of the stratal surfaces beneath a diprotodontid footprint (Fig. 9) transected by the joint, and (ii) undertracks of the same trackway that were impressed on a clinoform under $\leq 220 \mathrm{~mm}$ of sediment. 


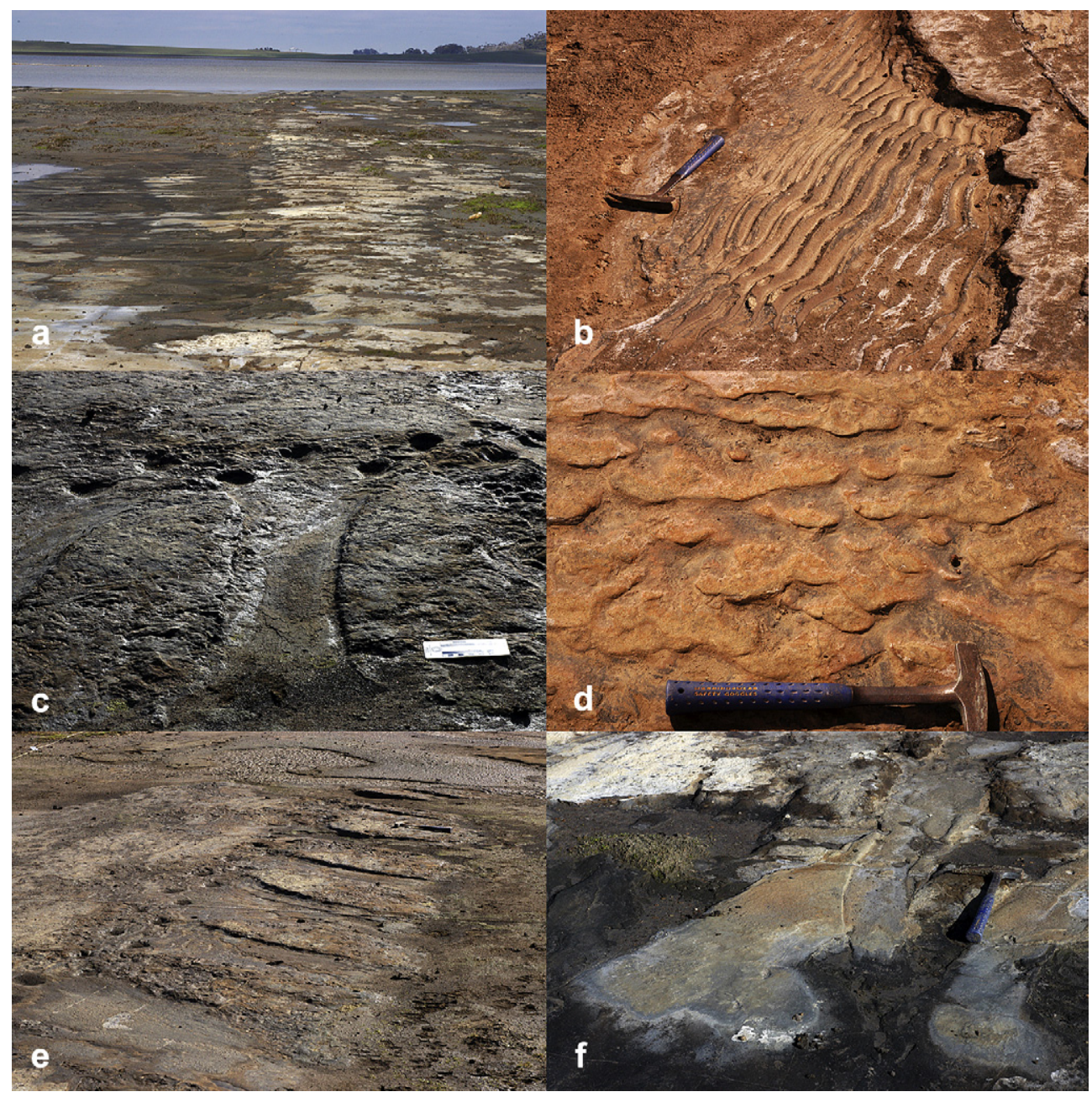

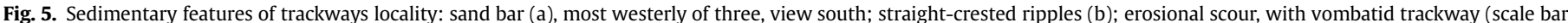

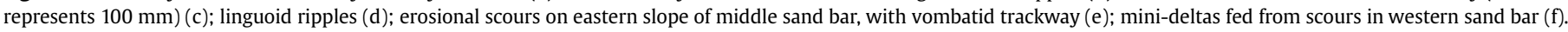

\subsection{Relation of geology to trackways}

The question of whether the trackways all developed on the same bedding surface was assessed on the basis of the following criteria: intersection/overlapping of trackways; proximity of trackways; and absence of breaks in the surface between trackways. All but two trackways can confidently be assigned to one of two surfaces, with those surfaces either being the same one or within a few very thin beds of each other (Table 3 ). One exception is T2 (vombatid) which is the only trackway on sand bar 3 and whose surface, on a clinoform, cannot be traced to the adjacent sand bars. The other exception is T15 (diprotodontid) which is separated from the other trackways by nearly $50 \mathrm{~m}$ and patchy vegetation.

In most cases the trackways-bearing bed is the uppermost volcaniclastic layer on each sand bar. Again, T2 is an exception, since the distal portion of the trackway is buried by very thin clinoformal beds of volcaniclastic sandstone. All trackways on a particular sand bar can be demonstrated to be formed in the same bed. Further, because T1, the main diprotodontid trackway, is exposed on sand bars 1 and 2, it provides the means to tie all the trackways on those two sand bars to the same surface. The two macropodid trackways north of sand bar 2 were imprinted into a bedding surface either identical to, or slightly above, that of the trackways on sand bar 2. As all trackways (except for T2 and T15) occur on, or extremely close to, the same bedding plane, they are here considered contemporaneous, representing a single accumulation over a short period of time (hours or days). T2 and T15 may have been formed at the same time as all the others; indeed, T15 may even be part of the same trackway as T1.

The only evidence of the order in which tracks were created is where the main diprotodontid trackway (T1) overprints one of the wombat trackways (T12) and thus must have formed slightly later.

First-order sedimentary features at the site exercise some control on the paths taken by at least some of the trackmakers. Variation in the character of individual trackways may be understood partly in terms of variation in the sedimentary character of the terrain across which the trackmaker moved.

\subsection{Track formation}

Almost all of the traces are true tracks (Lockley, 1991), the natural impressions left by the moving animals. A small number are undertracks, formed by the impact of feet on buried bedding surfaces (Lockley, 1986b). Several others are marked by a plug (Allen, 1997) of mounded sediment, the more resistant filling of a true track. Plug-style preservation is exhibited by some of the prints of T5 (Fig. 9) and T2. In no case is the texture of the animal's skin preserved, nor are striations derived from movement of textured skin through moist sediment (e.g. Milàn, 2006), probably because the host sediments are too coarse. 


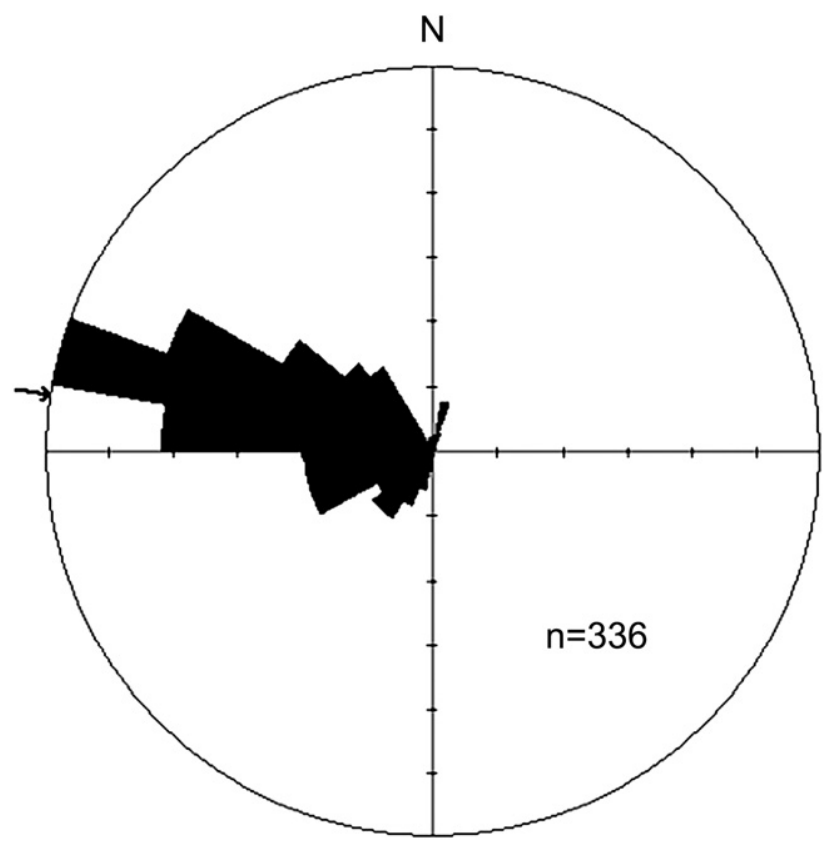

Fig. 6. Rose diagram showing generally westward transport direction of straightcrested and linguoid ripples. The mean transport direction (arrow) is to $278^{\circ}$ (95\% confidence interval $\pm 4^{\circ}$ ). The steeper face of each ripple is the lee slope. In the small proportion of ripples that are symmetrical, it is assumed that they were formed by waves travelling westward (onshore). Software used is Rod Holcombe's GEOrient.

Three types of print deformation occur (Fig. 9), notably in association with $\mathrm{T} 1$, made by the largest and heaviest trackmaker, the diprotodontid:

- Marginal ridge (Allen, 1997), a collar-like mounding of sediment around part or all of the print. Both the manus and the pes prints of $\mathrm{T} 1$ commonly feature a marginal ridge around the entire print. Where manus and pes prints overlap, the posterior border of the manus print is generally pushed forward.

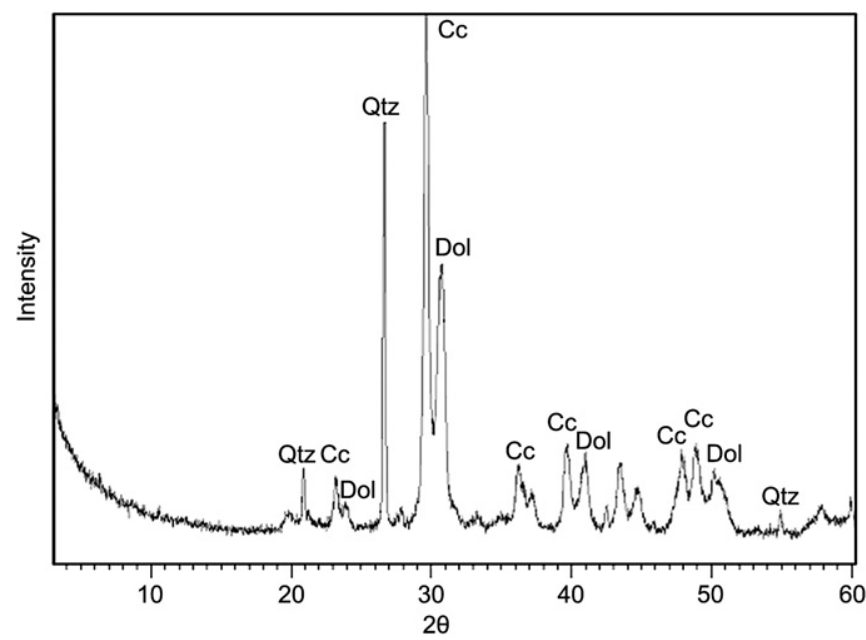

Fig. 8. X-ray diffractogram for sample of impure dolomitic limestone that overlies the trackways-bearing volcaniclastic sandstone. Abbreviations on peaks: $\mathrm{Cc}-\mathrm{Mg}$-calcite; Dol-ferroan dolomite; Qtz-quartz.

- Ejecta (Allen, 1997), sediment lobes (20-30 mm long, $30-40 \mathrm{~mm}$ broad and $\sim 10 \mathrm{~mm}$ high) ejected as saturated sediment from beneath the foot as it pressed upon the sediment surface. These are rare, associated with just two pairs of left manus and pes prints. In each case, the lobes occur on the inside (right side) of the print.

- Adhesion ridges, curvilinear to concentric ridges on the print's pad due to sticking by capillary action of the moist sediment to the base of the foot as the latter was raised.

The degree of deformation of the surrounding sediments in the diprotodontid and macropodid trackways is proportionally greater than in most other trackways (in some cases sediment is deformed for more than twice the length of the foot). This relates to the trackmakers' body mass, the speed at which they were travelling and the consequent force with which the prints were made.

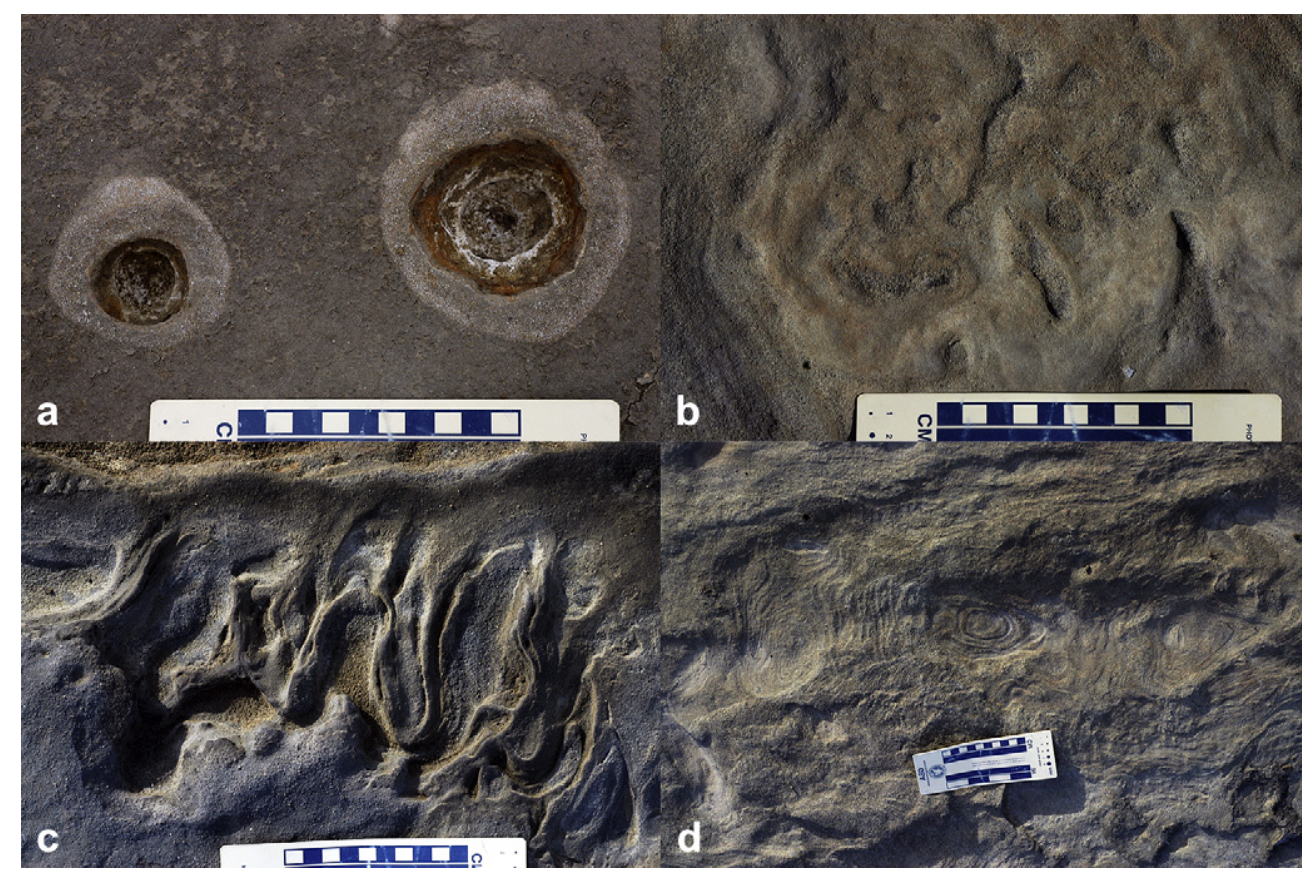

Fig. 7. Soft-sediment deformation, including bioturbation: plant moulds (a); invertebrate burrows (b); possible vertebrate undertracks (c, d). Scale bar represents 100 mm. 


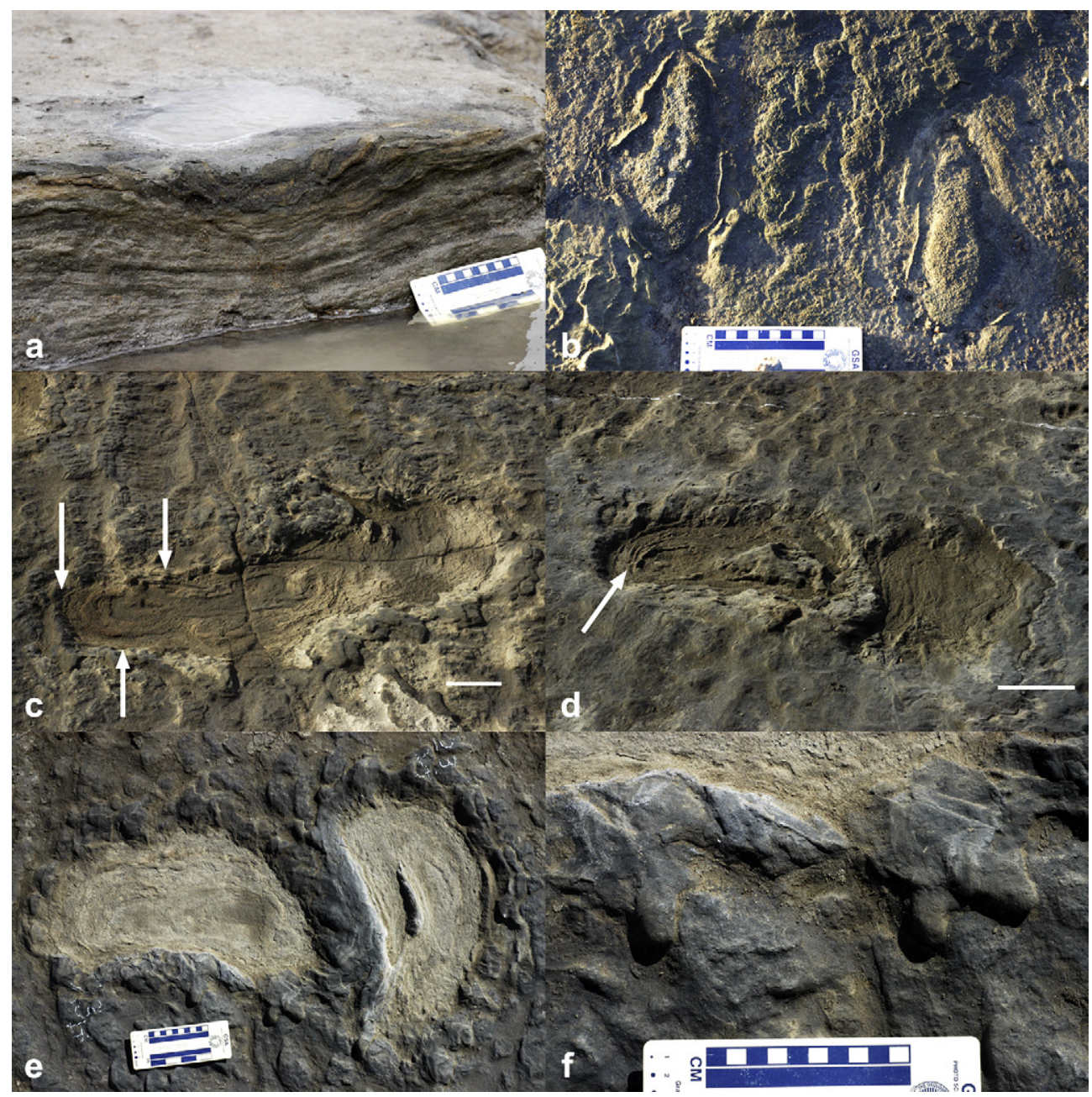

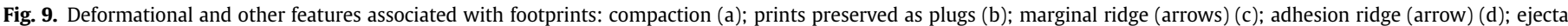
(e); ejecta (detail of e) (f). All from trackway T1 except (b) (T5). Scale bars represent $100 \mathrm{~mm}$; overlapping tracks in (c) $\sim 600 \mathrm{~mm}$ long; hind print in (d) $\sim 400 \mathrm{~mm}$ long.

\subsection{Description of trackways and identification of trackway makers}

A total of ten small-quadruped trackways, three macropodid trackways and two diprotodontid trackways are identified. The trackways vary in length from $1.2 \mathrm{~m}$ to $62.8 \mathrm{~m}$ (Table 4). The longest trackway, created by a diprotodontid, includes a gap of about $20 \mathrm{~m}$ where there are no impressions exposed.

\subsubsection{Diprotodontid trackways}

Two diprotodontid trackways, T1 and T15, are present. The latter is short and rather poorly preserved. It is located about $30 \mathrm{~m}$ northwest of the origin of the mapping grid (Fig. 2). Formed by an animal travelling south, it is possible that it was originally joined to T1

Table 1

Summary of trackway proportions measured at the site and proportions measured from a modern wombat (Vombatus ursinus) in a controlled environment.

\begin{tabular}{lllll}
\hline Trackway & $\begin{array}{l}\text { Average stride } \\
\text { length }(\mathrm{mm})\end{array}$ & $\begin{array}{l}\text { Average trackway } \\
\text { width }(\mathrm{mm})\end{array}$ & $\begin{array}{l}\text { Average pes } \\
\text { length }(\mathrm{mm})\end{array}$ & $\begin{array}{l}\text { Pace } \\
\text { angulation }\end{array}$ \\
\hline Diprotodontid & 1310 & 660 & 450 & $\begin{array}{l}89^{\circ} \\
\left(61^{\circ}-114^{\circ}\right)\end{array}$ \\
$\begin{array}{l}\text { Macropodid } \\
\text { Ramsayia? }\end{array}$ & 2000 & 230 & 185 & - \\
& 385 & 130 & 100 & $\begin{array}{l}105^{\circ} \\
\left(72^{\circ}-138^{\circ}\right) \\
110^{\circ} \\
\text { Vombatus }\end{array}$ \\
\begin{tabular}{c} 
ursinus \\
\hline
\end{tabular} & 390 & 120 & 130 & $\left(78^{\circ}-135^{\circ}\right)$ \\
\hline
\end{tabular}

through an arc that resulted in the animal's travelling south-east toward the palaeolake. The focus here is on $\mathrm{T} 1$.

4.5.1.1. Description and sedimentary context. The most prominent trackway, T1, (Figs. 2, 10 and 11) is remarkable for its length $(62.8 \mathrm{~m}$, though with a gap of $20.2 \mathrm{~m}$ included) and the size of the individual footprints (hind prints generally $35-40 \mathrm{~cm}$ long). The prints are variable in size and shape. The best preservation of footprint morphology occurs on the crests of the first two sand bars. Since it is headed south-east, it crosses all three mapped sand bars but is not exposed on sand bar three (Fig. 2). Across the broad crest of sand bar 1, the manus prints (short) and the pes prints (long) are separate (i.e. not overlapping, Fig. 12). They are typically impressed 30-40 $\mathrm{mm}$ into the sediment surface and many feature a marginal ridge. At the brink of the first sand bar, beyond which it slopes to

Table 2

Pace angulation averages and ranges measured for selected fossil vombatid trackways, as well as for trackways formed by a modern wombat.

\begin{tabular}{ll}
\hline Trackway & Pace angulation \\
\hline T2 & $99^{\circ}\left(72^{\circ}-138^{\circ}\right)$ \\
T4 & $112^{\circ}\left(102^{\circ}-116^{\circ}\right)$ \\
T12 & $107^{\circ}\left(40^{\circ}-155^{\circ}\right)$ \\
Vombatus ursinus walk & $110^{\circ}\left(78^{\circ}-135^{\circ}\right)$ \\
V. ursinus trot & $157^{\circ}\left(154^{\circ}-160^{\circ}\right)$ \\
\hline
\end{tabular}


Table 3

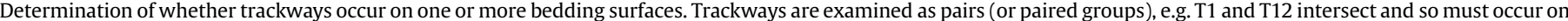

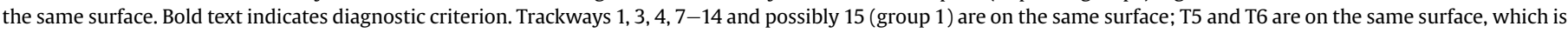
very close to, if not the same as, the surface hosting group 1; and T2 is on a different (but possibly coeval) bedding surface.

\begin{tabular}{|c|c|c|c|c|}
\hline $\begin{array}{l}\text { Trackway } \\
\text { pairing }\end{array}$ & Sand bar & $\begin{array}{l}\text { Common surface } \\
\text { features }\end{array}$ & Remarks & Conclusion \\
\hline $1-3$ & 1 & $\begin{array}{l}\text { Large-amplitude ripples } \\
\text { (mostly straight to somewhat sinuous) }\end{array}$ & Proximity ( $1 \mathrm{~m}$ apart), no breaks & Same surface \\
\hline $1-12$ & 2 & Ripples linguoid & Trackways intersect & Same surface \\
\hline $1-10$ & 2 & Ripples linguoid & $\mathrm{T} 10$ in between left \& right trains of $\mathrm{T} 1$ & Same surface \\
\hline $1-8$ & 2 & Ripples linguoid \& sinuous & Proximity ( $5 \mathrm{~m}$ apart), no breaks & Same surface \\
\hline $12-13$ & 2 & Ripples linguoid & Trackways intersect & Same surface \\
\hline $7-9$ & 2 & Ripples sinuous, carbonate crust & Proximity (1.5 m apart), no breaks & Same surface \\
\hline $1 / 8 / 10 / 12-7 / 9$ & 2 & $\begin{array}{l}\text { Ripples sinuous, carbonate crust } \\
\text { (in part) }\end{array}$ & Proximity (3-4 $\mathrm{m}$ apart), no breaks & Same surface \\
\hline $4-12$ & 2 & Ripples linguoid & Proximity ( $1 \mathrm{~m}$ apart), no breaks & Same surface \\
\hline $4-14$ & 2 & Ripples linguoid & Proximity ( $2 \mathrm{~m}$ apart), no breaks & Same surface \\
\hline $5-6$ & North of 2 & Planar & Proximity ( $3 \mathrm{~m}$ apart), no breaks & Same surface \\
\hline $4-6$ & $2 ;$ north of 2 & Planar at T6, linguoid ripples at T4 & $\begin{array}{l}\text { Proximity ( } 3 \mathrm{~m} \text { apart) on depositional strike; } \\
\text { break: scouring \& modern erosional fretting }\end{array}$ & Same/similar surface \\
\hline 2 & 3 & & Clinoform & No relationship demonstrable \\
\hline 15 & - & & $\begin{array}{l}\text { NW of grid; surface directly overlain, } \\
\text { in part, by dolomitic limestone; surface } \\
\text { rippled (sinuous-crested) }\end{array}$ & $\begin{array}{l}\text { Probably same surface as that of most } \\
\text { trackways, from which micritic carbonate } \\
\text { believed stripped }\end{array}$ \\
\hline
\end{tabular}

the east, a compound right footprint exists, where one foot has made three overlapping impressions, i.e. a shuffling of the foot where the animal hesitated to step down from the first sand bar (Fig. 10). Most of the prints from beyond the brink to the step before the second sand bar are subtle to barely distinguishable. The surface concerned is a clinoform, being planar (i.e. having no bed forms) and dipping at up to $8^{\circ}$ east before becoming horizontal at a step in the exposure along a joint. The overlying clinoforms have been removed by unknown means at some time in the past between the brink of sand bar 1 and the joint. Thus the subtle, saucer-shaped prints of the clinoform are undertracks, formed on a buried stratal surface due to compaction under the feet of the diprotodontid. A section through successive undertracks is exposed where a vertical joint intersects a print of the left pes (that is, the stratification displays the degree of compaction beneath the weight of the animal; Fig. 9).

Across sand bar 2, the prints are generally more uniform in size and shape than elsewhere, despite the manus and pes prints commonly overlapping (Fig. 13). Of the deformational features described above, adhesion ridges and anterior marginal ridges on the pes prints are common, and the only ejecta observed occur

Table 4

Identifier, perpetrator, locations of commencement and termination, and travel direction of each trackway. Locations are in metres and measured with respect to the origin of the grid established for the purpose.

\begin{tabular}{|c|c|c|c|c|c|c|}
\hline \multirow[t]{2}{*}{ Trackway ID } & \multirow[t]{2}{*}{ Track maker } & \multicolumn{2}{|c|}{ Beginning } & \multicolumn{2}{|l|}{ End } & \multirow{2}{*}{$\begin{array}{l}\text { Travel } \\
\text { direction }\end{array}$} \\
\hline & & Easting & Southing & Easting & Southing & \\
\hline $\mathrm{T} 1$ & Diprotodontid & 4.45 & 35.79 & 65.10 & 60.75 & $\mathrm{SE}$ \\
\hline $\mathrm{T} 2$ & Vombatid & 54.86 & 38.77 & 57.37 & 20.23 & $\mathrm{~N}$ \\
\hline T3 & Macropodid & 6.20 & 32.83 & 5.95 & 16.59 & $\mathrm{~N}$ \\
\hline $\mathrm{T} 4$ & Vombatid & 24.81 & 40.50 & 32.86 & 26.64 & SW \\
\hline T5 & Macropodid & 38.24 & 11.86 & 38.66 & 1.23 & $\mathrm{~N}$ \\
\hline T6 & Macropodid & 34.92 & 17.87 & 36.50 & 14.09 & $\mathrm{~N}$ \\
\hline $\mathrm{T} 7$ & Vombatid & 28.83 & 55.25 & 28.65 & 60.80 & $\mathrm{~S} / \mathrm{N}$ \\
\hline T8 & Vombatid & 33.95 & 54.40 & 21.86 & 46.45 & NW \\
\hline T9 & Vombatid & 30.05 & 55.38 & 27.90 & 53.31 & $\mathrm{~S} / \mathrm{N}$ \\
\hline T10 & Vombatid & 30.71 & 52.38 & 31.94 & 52.83 & SE \\
\hline T11 & Thylacoleo? & 35.40 & 47.23 & 34.72 & 46.06 & NW \\
\hline T12 & Vombatid & 25.22 & 44.97 & 25.93 & 40.32 & $\mathrm{~N}$ \\
\hline T13 & Vombatid & 25.70 & 42.60 & 26.87 & 41.96 & $\mathrm{E}$ \\
\hline T14 & Vombatid & 27.15 & 34.05 & 26.99 & 28.94 & $\mathrm{~N}$ \\
\hline T15 & Diprotodontid & -12.50 & -47.90 & -17.60 & -29.80 & $\mathrm{~S}$ \\
\hline
\end{tabular}

here. On the eastern slope of sand bar 2 and in the subsequent shallow trough, the morphological details of the fore and hind prints are lost in favour of a broad saucer shape. While the saucershaped prints may be undertracks, it is also possible that they are true tracks formed in saturated sediment lacking cohesion.

Following a 20-m gap in the trackway, a final set of indistinct diprotodontid prints almost directly in line with the main part of the trackway is interpreted to represent the termination of the preserved diprotodontid trackway. While slightly smaller than the well formed prints, they are much larger than all other prints at the locality and are, as a consequence, inferred to be a continuation of the diprotodontid trackway made in wet sediment.

4.5.1.2. Identity of trackmaker. Due to the size of the footprints in trackway T1, the majority of the known megafauna can be ruled out as the trackmaker. Only three species, $D$. optatum, $Z$. trilobus and Palorchestes azael, were big enough. P. azael is relatively rare in the fossil record, and possesses a most distinctive pedal morphology, while the other two species were common in south-eastern Australia during the late Pleistocene. In at least one pes print, a divergent first digit is clearly discernible (Fig. 13), a character we regard as critical to identification. The first metacarpal, or hallux, of D. optatum projects medio-posteriorly and is effectively part of the tarsus, and metatarsals II and III are severely reduced in size and project antero-medially (Fig. 14). The hallux and metatarsals II and III of $Z$. trilobus are proportionally larger than in D. optatum, the hallux projecting medially and the other metatarsals projecting more anteriorly. The morphology of the prints is a much better match with the foot structure of $D$. optatum than that of $Z$. trilobus. Weisbecker and Archer (2008) noted that the digital proportions in the manus of Diprotodon are plesiomorphic, being most similar to those seen in arboreal taxa such as possums. They also implied that there has been little selective pressure placed on the digits of Diprotodon and consequently that they may not have been employed during locomotion. This helps explain the morphology of the manual prints in the diprotodontid trackway (T1) where it is inferred that only carpal and metacarpal pads are evident.

Another method of assessing the identity of the trackmaker employs the trackway proportions. The ratio of foot length to trackway width in the D. optatum trackway at Lake Callabonna was approximately 0.73 , based on extrapolation of measurements and photographs taken by Richard Tedford in 1970 (pers. comm. 2007). 


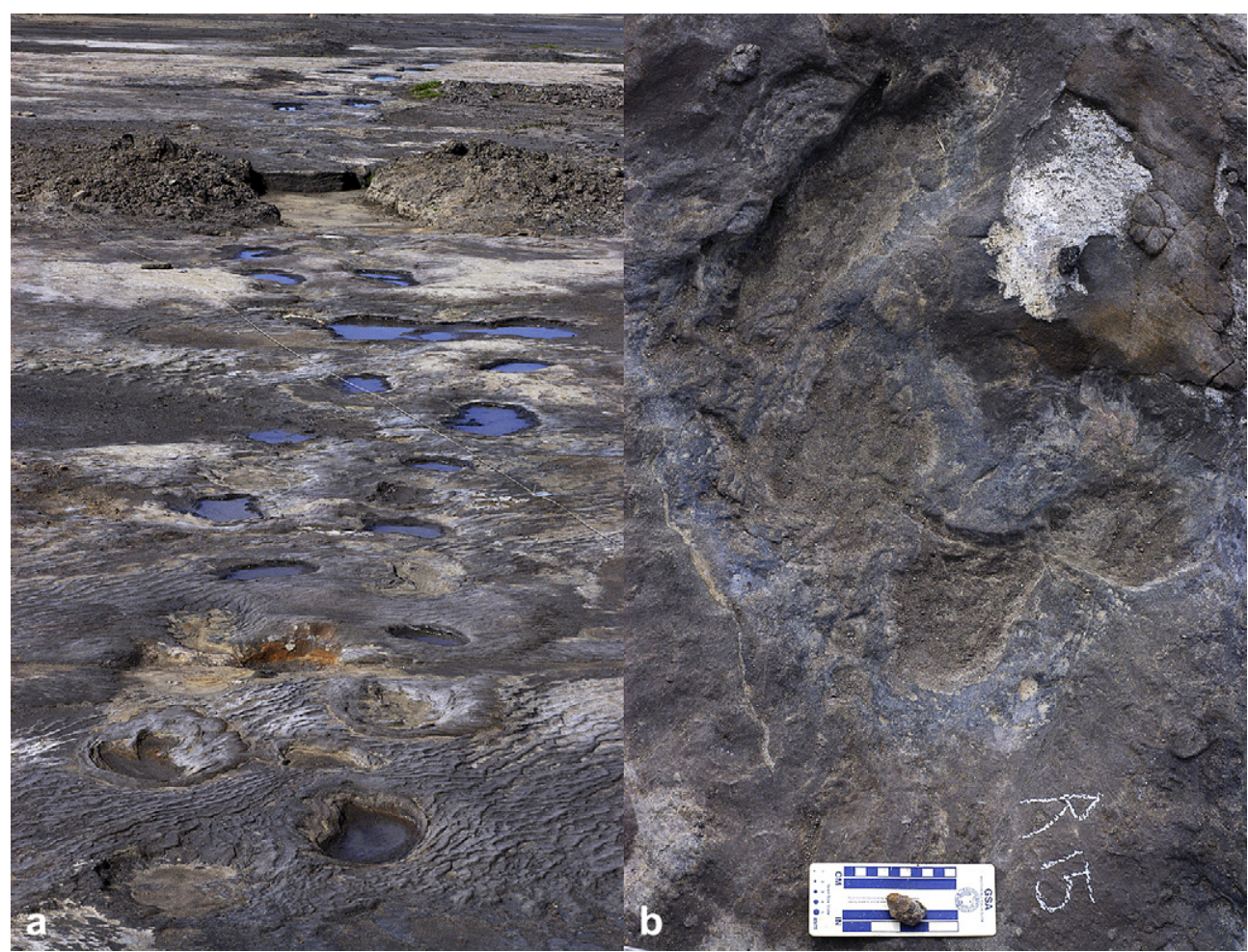

Fig. 10. Diprotodontid trackway, T1: view from proximal end of trackway along $30 \mathrm{~m}$ of its length (a); prints are filled with rainwater; depression at about midpoint is where a length of about $2 \mathrm{~m}$ of section has been removed, and subtle undertracks are exposed; view to south-east. (b) Complex of prints at brink of western sand bar indicating shifting of foot (hesitation) as animal prepared to step off crest of sand bar.

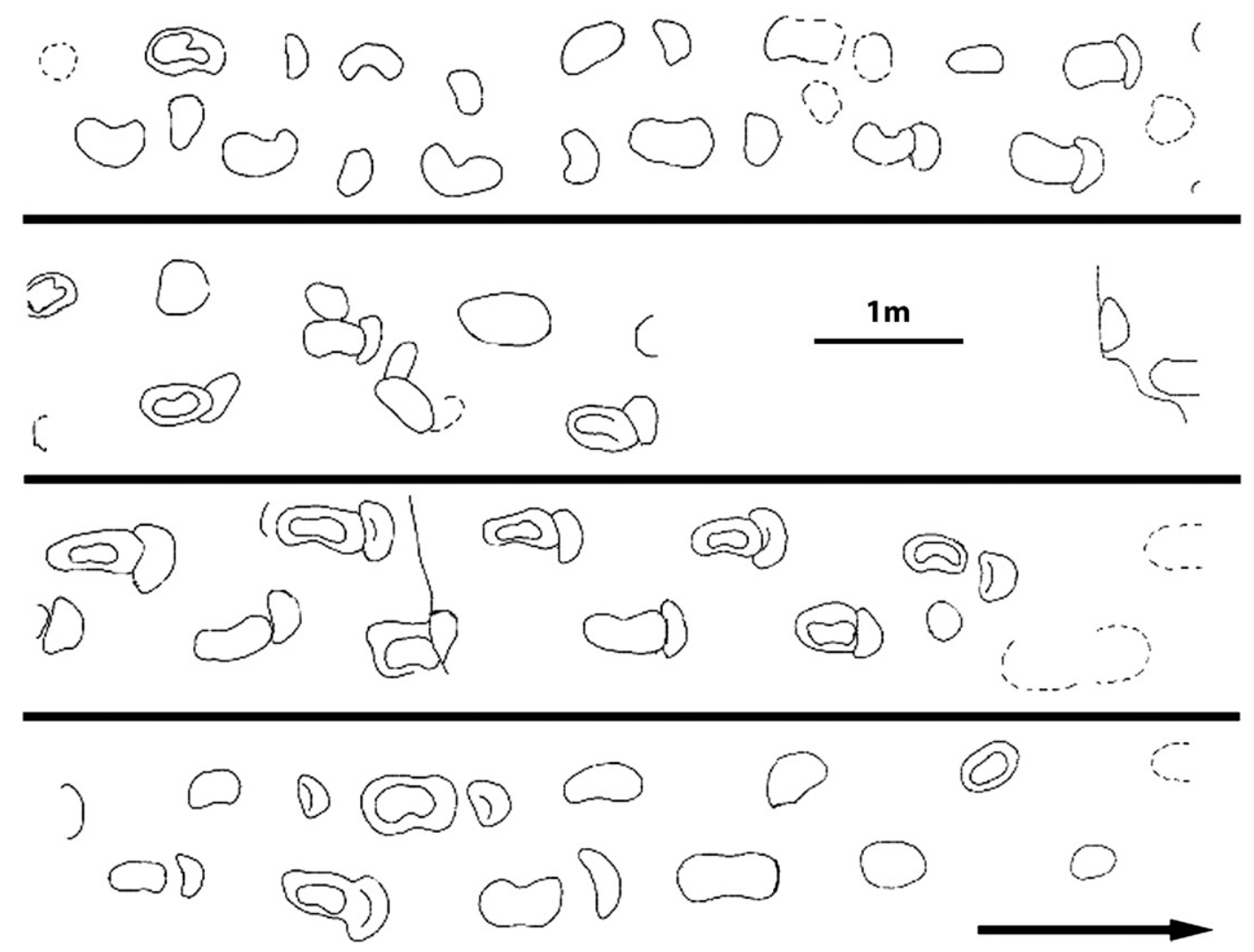

Fig. 11. Schematic displaying entire diprotodontid trackway (T1); trackway proceeds from left to right, top to bottom. 


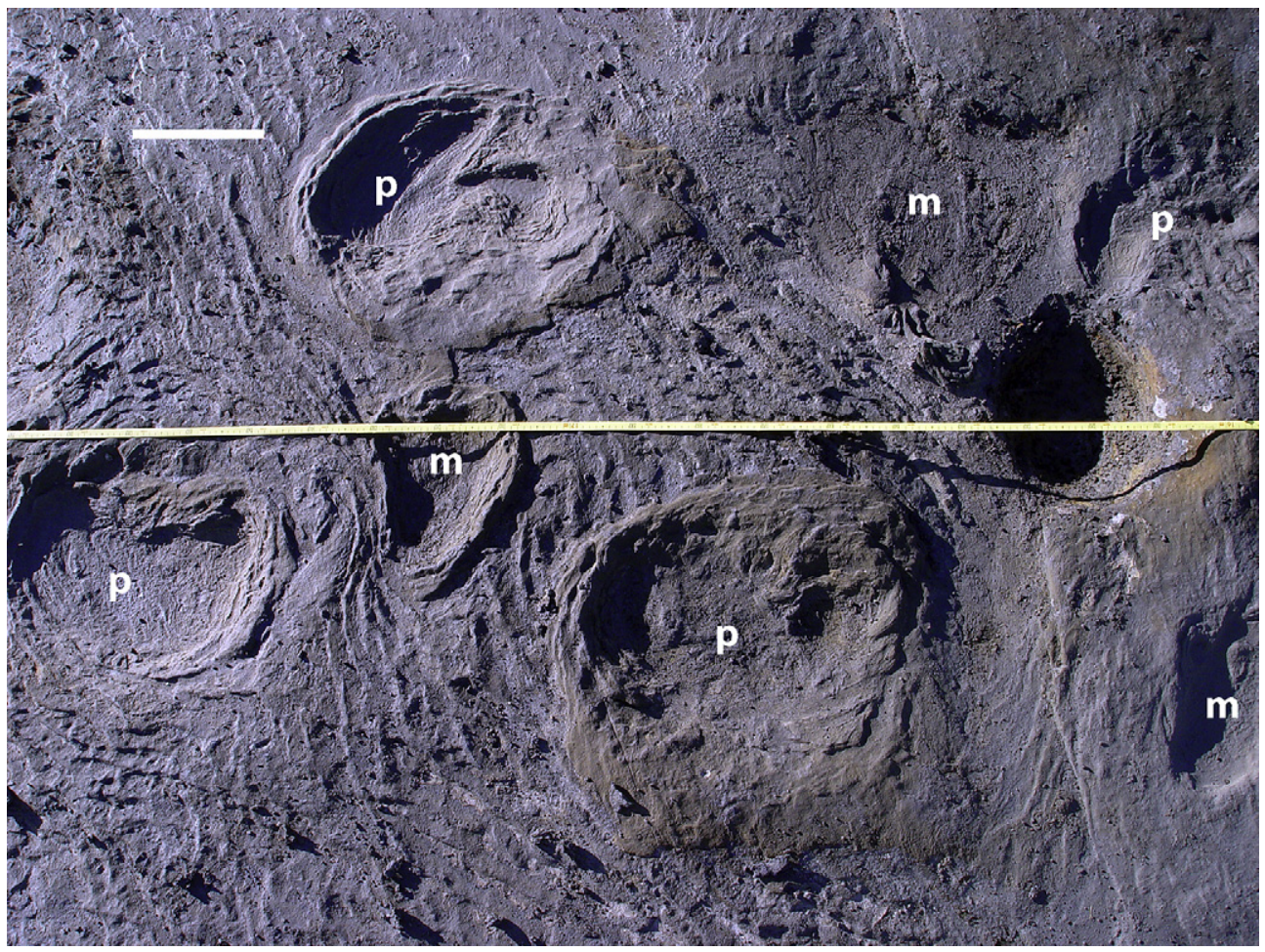

Fig. 12. Proximal section of the diprotodontid trackway (T1) displaying separate manus (m) and pes (p) prints. Scale bar represents 200 mm.

The same ratio, determined from the mounted skeleton of $D$. optatum in the South Australia Museum, is 0.53. The difference between these two values probably reflects the walking (Callabonna) versus standing (SAM) positions of the limbs. The ratio calculated from the VVP trackway is 0.41 , much closer to expectation for $Z$. trilobus (approximately 0.4 based on the mounted specimen at the Queen Victoria Museum and Art Gallery) than for D. optatum. Henderson (2006) demonstrated that while the detail of fossil prints can be lost through erosion the dimensional ratios remain constant, and so the inferences made from the ratios determined from the trackways measured in this study are probably valid. The ratio can be expected to be higher in a moving animal than a stationary animal because the feet land closer together as speed increases (see Bang, 2001), while they are spread apart for stability when the animal is stationary. The average pace angulation measured for diprotodontid trackway $\mathrm{T} 1$ is $89^{\circ} \pm 11^{\circ}\left(64^{\circ}-114^{\circ}\right)$ while in diprotodontines for which trackways are known (Euowenia grata and D. optatum) the angulation is around $125^{\circ}$. A lower value suggests that the limbs are being held further apart, in a more sprawling gait (Lockley and Meyer, 2000 , p. 3). The trackway parameters of $\mathrm{T} 1$ - specifically, track width in relation to foot length and pace angulation - match more closely those expected of $Z$. trilobus than of $D$. optatum. If the animal responsible was $Z$. trilobus then the individual was moving at relatively high speed (as indicated by the ratio of stride length to foot length) for parts of the trackway and must have employed a gait other than a walk, such as a trot. In order to calculate an approximate speed of travel, we assumed a hip height of around $830 \mathrm{~mm}$ for D. optatum and $600 \mathrm{~mm}$ for Z. trilobus (see Materials and Methods section). The gleno-acetabular length, calculated from the trackway measurements using Haubold's formula (see Table 1), would have been approximately $1080 \mathrm{~mm}$. These measurements suggest the average speed of travel was $5 \frac{1}{2} \mathrm{~km} / \mathrm{h}$ for $D$. optatum or $8 \mathrm{~km} / \mathrm{h}$ for Z. trilobus.

Kardong (2002, p. 334) posited that a trotting gait provides a stable method of locomotion at increased speeds for animals with broad bodies such as hippopotamuses. Z. trilobus, which has been likened to a marsupial hippopotamus or rhinoceros (Scott and Lord, 1920a), could also have adopted this gait to move at faster speeds. Murie (1954) reported that most quadrupedal animals moving at a walk, from bears to ungulates, have tracks with the manus impression placed just in front of, or overprinted by, the pes impression, and that as the animal picks up speed the pes prints fall in front of the manus prints. When wombats employ a trotting gait, the pes more completely overprints the manus than when they walk. The morphological similarities between $Z$. trilobus and wombats have long been recognised (e.g. Scott, 1915; Scott and Lord, 1920b,c) and the former probably employed a sprawling gait similar to the latter's. The VVP trackway displays almost complete overlap of the manus and pes prints across sand bar 2, suggesting the animal was moving faster, while, closer to the beginning of the trackway (sand bar 1), the prints do not overlap at all, an indication that the animal was moving more slowly. Thus it seems that the animal was moving at a trot, similar to that employed by Vombatus ursinus, for at least part of the trackway.

Alexander (1984) suggested that the Froude number, $F_{\mathrm{r}}$, can be used to determine an animal's probable gait at a given speed. $F_{\mathrm{r}}$ can be calculated from the formula $\mathrm{u}^{2} / \mathrm{gh}$ where $\mathrm{u}$ is the speed in $\mathrm{ms}^{-1}$, $\mathrm{g}$ is the acceleration due to gravity $\left(9.8 \mathrm{~ms}^{-2}\right)$ and $\mathrm{h}$ is the hip height in metres. Alexander concluded that, at $F_{\mathrm{r}}=0.1$, most animals employ an ambling gait (or walk); at $F_{\mathrm{r}}=1$, they move into a trotlike gait; and, at $F_{\mathrm{r}}$ between 2 and 3, the motion is a canter or gallop. If $Z$. trilobus were responsible for $\mathrm{T} 1, F_{\mathrm{r}} \approx 0.8$, indicating a trot, whereas if the species responsible were $D$. optatum, $F_{\mathrm{r}} \approx 0.3$, suggesting an amble or walk.

Although the ratios and sedimentary deformational features presented above suggest that these tracks represent $Z$. trilobus, rather than $D$. optatum, the print morphology clearly demonstrates that the latter species was responsible for these tracks. This alters our understanding of the gait of $D$. optatum. Thus $D$. optatum did not always walk with the limbs upright under the body, as indicated by 


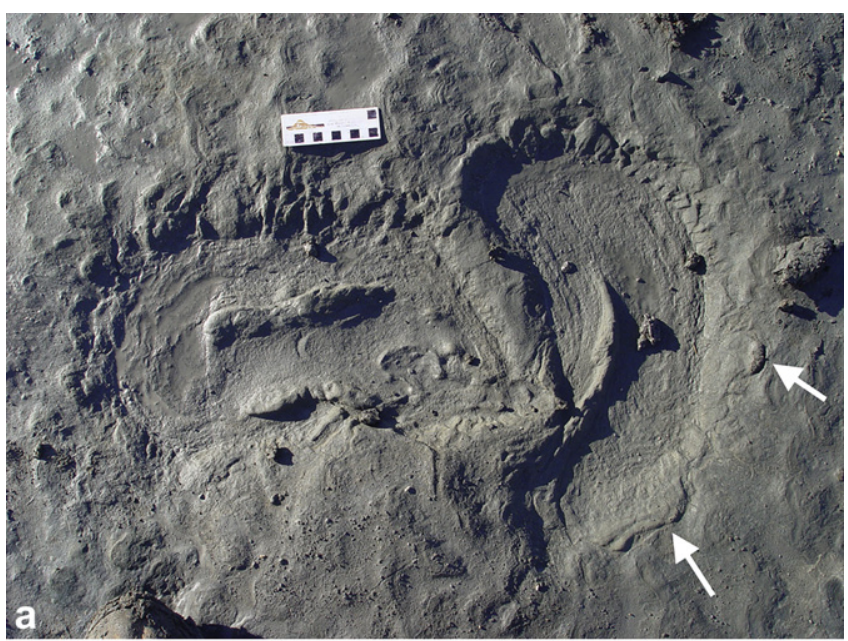

b

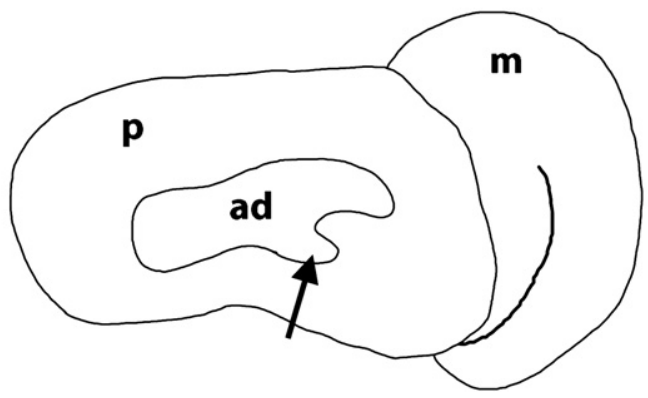

Fig. 13. Diprotodontid prints from trackway $\mathrm{T} 1$ displaying hindfoot overprinting forefoot (a) and morphological interpretation (b). Abbreviations: $m$-manus print, $\mathrm{p}$-pes print, ad-adhesion trace (records some features of pad morphology). The ridge seen inside the manus print is interpreted to represent the space between the carpal and metacarpal pads; the manus print shows lateral slippage occurred when the foot was set down. White arrows indicate sediment ejecta, the black arrow indicates the impression of the first metatarsal. Scale bar represents $100 \mathrm{~mm}$.

the Callabonna trackways (Camens and Wells, 2009), but was able to vary limb position, and hence trackway gauge, considerably during locomotion.

\subsubsection{Macropodid trackways}

Three macropodid trackways were identified based on pad morphology and the pairing of prints, indicative of a hopping

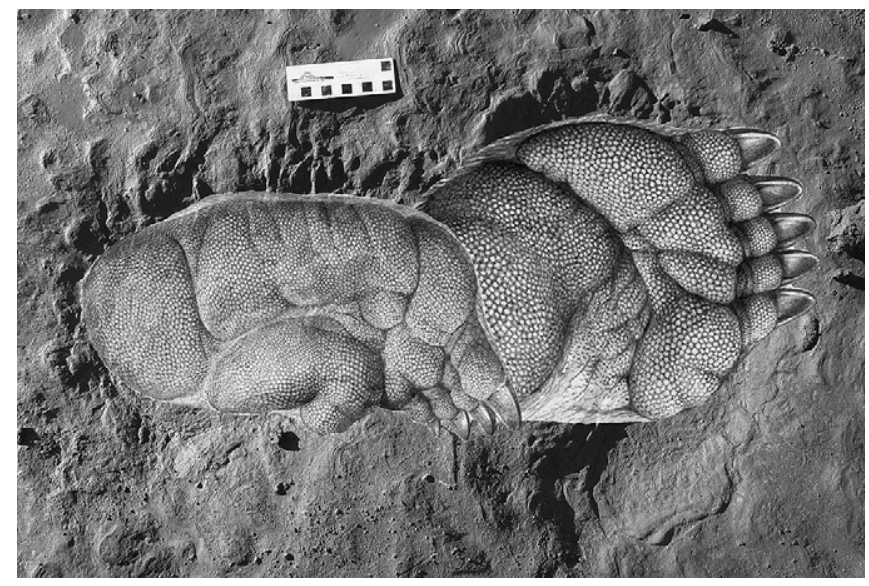

Fig. 14. Diprotodontid manus and pes print (trackway T1) with reconstruction of Diprotodon manus and pes overlaid (reconstruction by P. Trusler). Scale bar represents $100 \mathrm{~mm}$. (ricochetal) gait. Each trackway consists of 3-7 pairs of prints, the average dimensions as in Table 1 . In T3, the whole foot has been placed on the ground in the penultimate pair of prints, while for the other prints in the trackway only the toe imprints are preserved.

The pad impressions seen in these trackways reveal the imprints of two large digits, interpreted to be the fourth and fifth digits. These indicate that the trackmaker was not a sthenurine (extinct, short-faced kangaroo), as this group of macropodids had only one large digit (the fourth) in the pes (Wells and Tedford, 1995). Possible trackmakers include a number of species from the two genera Macropus (modern kangaroos) and Protemnodon (extinct grazing kangaroos). Protemnodon species are known to have had a proportionally larger fifth digit than modern kangaroos (Stirton, 1963, p.132), as is observed in the fossil footprints (Fig. 15). However, it is not possible to rule out species such as Macropus rufogriseus (the red-necked wallaby) that also have an enlarged fifth digit. The proportionally large size of the fifth digit in the pes of the trackmaker most likely excludes modern species of large kangaroos such as M. rufus, Macropus giganteus and M. robustus. Triggs (2004) suggested that the digital pads of modern wallabies such as M. rufogriseus leave tracks up to about $120 \mathrm{~mm}$ long. The animals that created the fossil tracks left digital-pad impressions averaging $185 \mathrm{~mm}$ in length, indicating that a species larger than modern wallaby species, such as Protemnodon anak or $P$. roechus, was responsible. Where the whole foot is imprinted, the length of the footprint is about $350 \mathrm{~mm}$ (Fig. 16). Stirton (1963) noted that the pes of Protemnodon was proportionally shorter than those of modern wallabies and hence a pes length of $350 \mathrm{~mm}$ may represent a large Protemnodon individual (the unnumbered cast of a large, adult Protemnodon in the Queen Victoria Museum and ArtGallery has a pes length of $360 \mathrm{~mm}$ ). Belperio and Fotheringham (1990) attributed a fossil macropodid trackway to Protemnodon based on
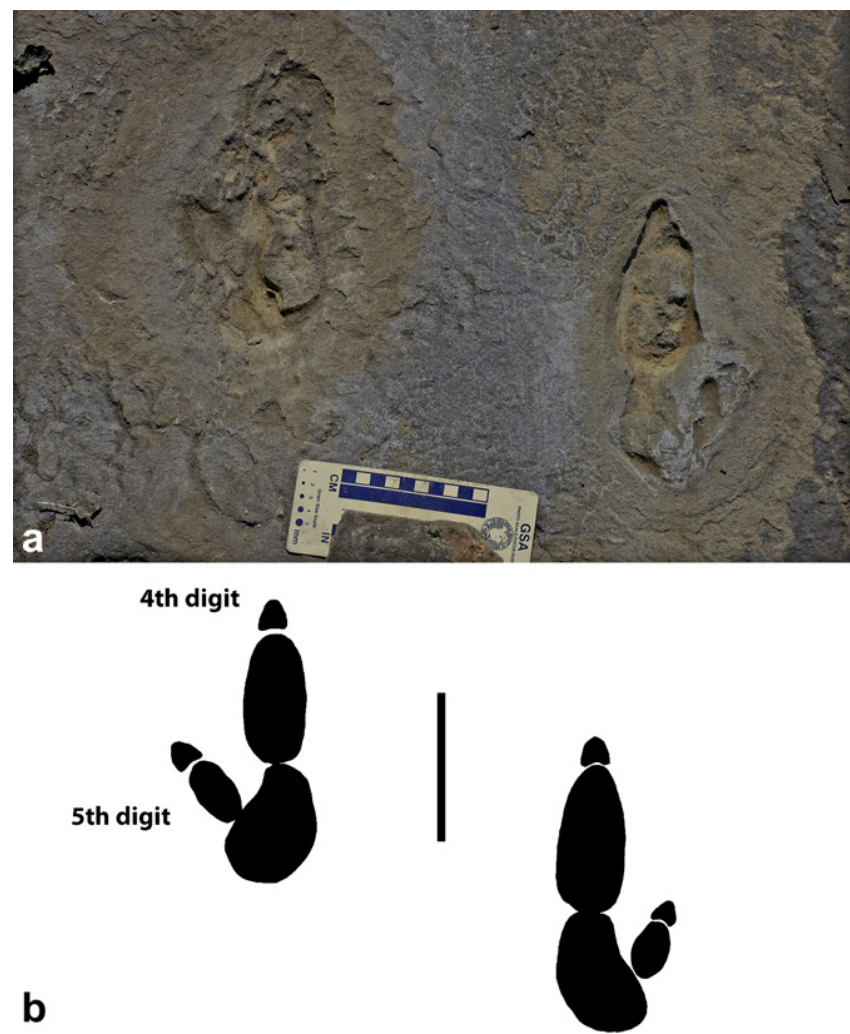

Fig. 15. Macropodid digital pad prints from trackway T5 displaying the large 5th digit (a). Interpretation of the displayed pad morphology (b). Scale bar represents $100 \mathrm{~mm}$. 


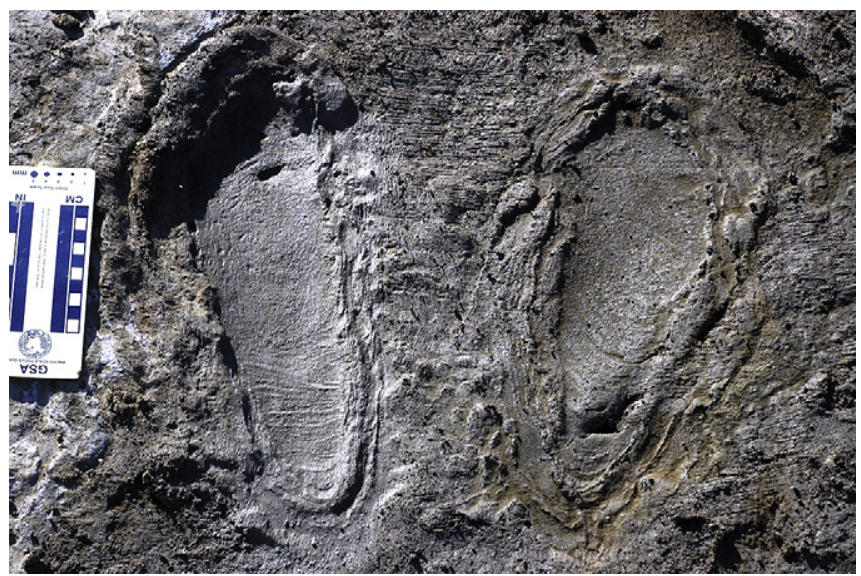

Fig. 16. Macropodid prints from trackway T3. This pair is atypical in representing the whole of each foot rather than just the digits. Scale bar represents $100 \mathrm{~mm}$.

the large imprint of the fifth digit. The tracks described by these authors were $280 \mathrm{~mm}$ long, making them significantly larger than those described here (see Table 1 ).

\subsubsection{Vombatid trackways}

Ten of the 15 trackways were made by small quadrupeds, mostly wombats (Table 4). We describe the three longest and most distinct of the vombatid trackways, T2, T4 and T12.

4.5.3.1. Description and sedimentary context. The entirety of $\mathrm{T} 2$ occurs on the east-dipping steeper slope of the northerly oriented sand bar 3 (Figs. 2 and 17), never more than $20-30 \mathrm{~cm}$ east of the sand bar's brink. Nearly $19 \mathrm{~m}$ long and consisting of 98 footprints (usually consisting of the proximal foot pads but occasionally displaying digital morphology), it is directed northerly and disappears progressively (first the right prints, then the left prints) under easterly dipping planar clinoforms. In three instances, small erosional scours each obliterate a footprint. Such scours, incised into the eastern slope of the sand bar and directed easterly, are common at the southern end of the trackway, but disappear northward. The footprints at the southern end of the trackway become progressively less distinct until they can no longer be resolved.

Trackway T4 is confined to the top of sand bar 2 (Figs. 2 and 17), is $16.6 \mathrm{~m}$ long and is composed of 86 prints. Initially directed south, it heads south-west from a dogleg at a distance of $4.4 \mathrm{~m}$ along the trackway. Most of the prints are of the proximal foot pads, some also displaying digital impressions (Fig. 18), while the very first print is represented only by digital pad impressions. The initial southward-directed segment is high on the eastern slope of the sand bar and parallel to the brink line. The first print is separated from the next prints by a small current scour directed easterly down the eastern slope of the sand bar, and the third pair of prints, located in another shallow scour, is barely discernible due to penecontemporaneous erosion. Most of the sand bar's surface is rippled so that many of the footprints are difficult to discern. The south-westerly segment of the trackway records the animal travelling diagonally across the sand bar. The trackway ends amongst linguoid ripples, where the prints are very subtle.

Trackway T12 (Fig. 18) is distinguished from T2 and T4 in that most of the prints represent the digital pads, with the remainder of the footprint rarely being preserved. It is located on the crest of sand bar 2 (Fig. 2), heads north, is $4.7 \mathrm{~m}$ long and consists of 44 prints. While the surface is covered with linguoid ripples, the puncture-like prints of the digital pads are generally very clear. Just after the beginning of the trackway, there is a short gap where a diprotodontid track has obliterated several vombatid prints.

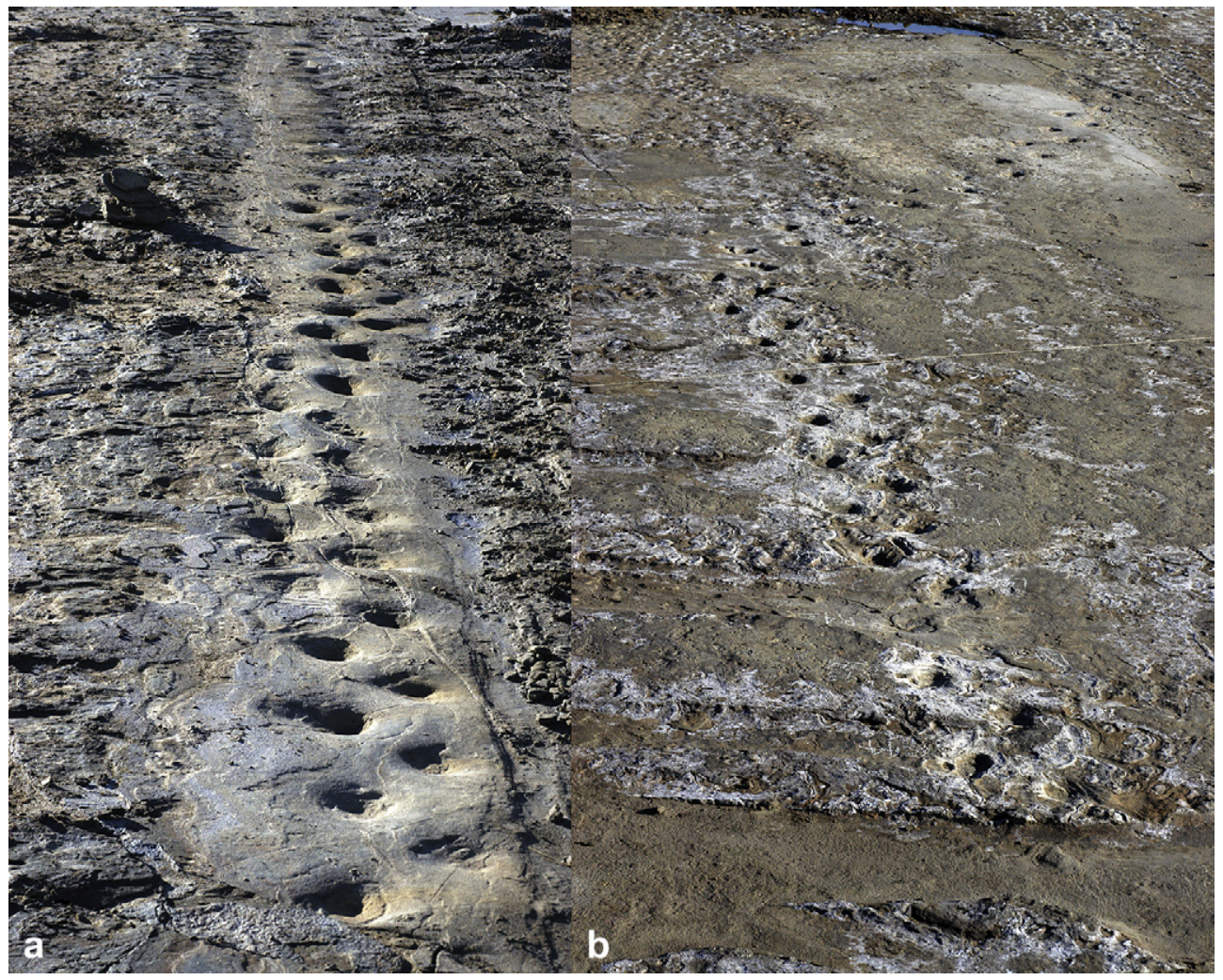

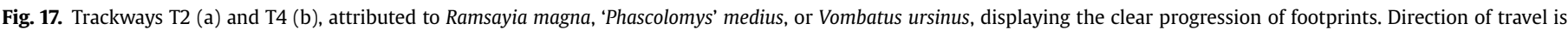
towards top of picture in both (a) and (b). 

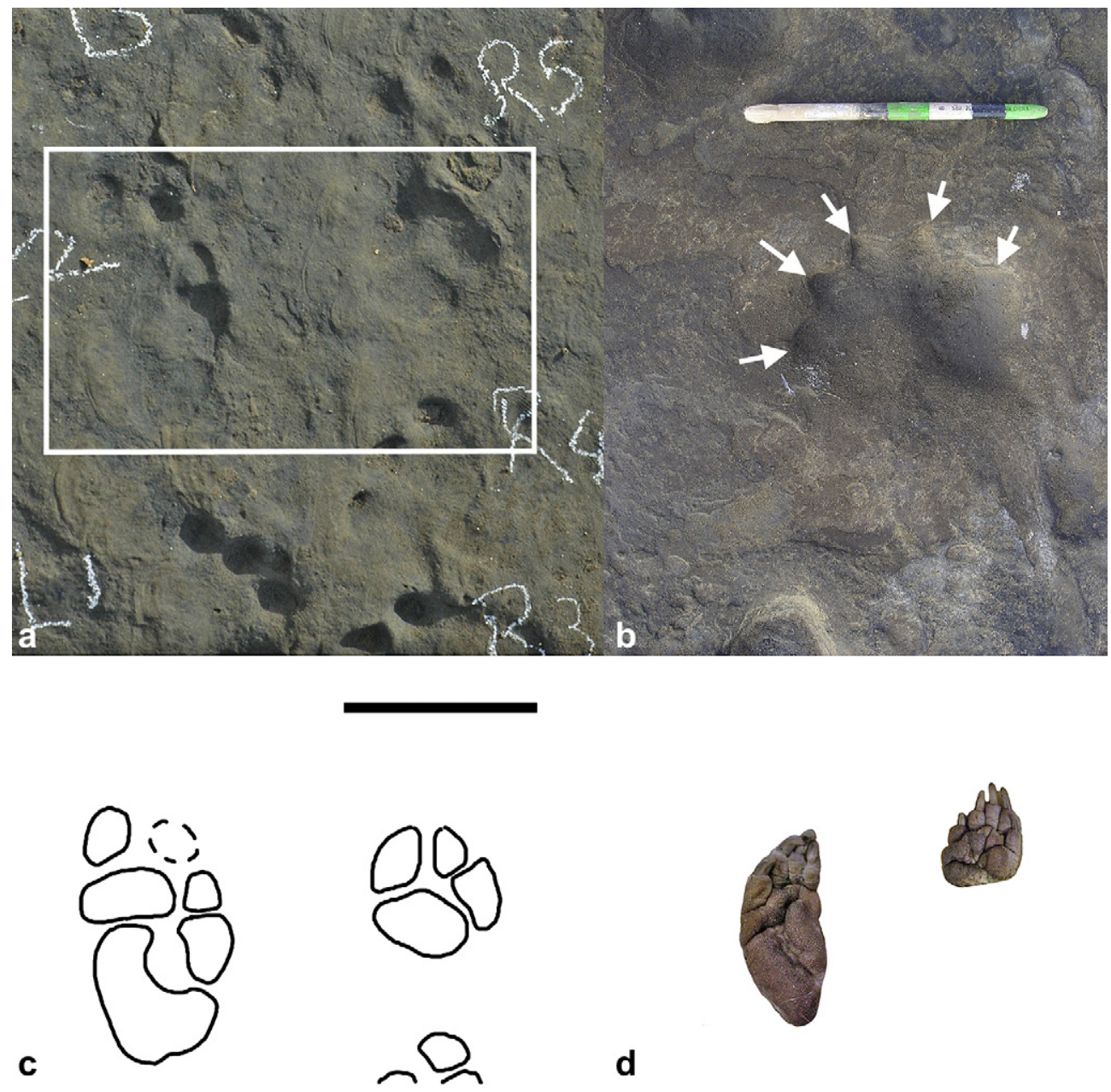

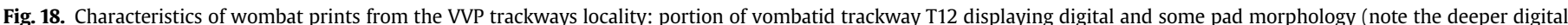

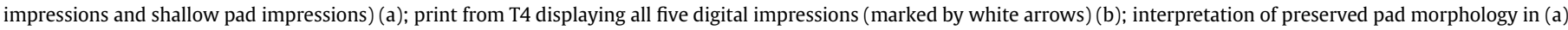
(from white square) (c); fleshy manus and pes of adult Lasiorhinus latifrons (southern hairy-nosed wombat) (d). All images are to same scale, scale bar represents 100 mm.

4.5.3.2. Identification of trackmaker. The identification of the taxon responsible for these trackways is problematic due to the partial preservation of the prints and the wide range of potential candidates. The latter include Sarcophilus laniarius (a larger version of the modern Tasmanian devil), Thylacinus cynocephalus (the Tasmanian tiger), Thylacoleo carnifex (the marsupial lion), multiple species of wombat and even a juvenile diprotodontid. Dasyurid (e.g. Tasmanian devil) prints tend to have long, thin digit impressions with complex pad morphology while thylacine prints display four digits of equal size (Triggs, 2004), neither of which matches the print morphology observed in the fossil trackways.

Of the ten small-quadruped trackways identified, it is likely that most were from the same species, though not necessarily the same individual. This is despite quite variable preservation, including tarsal/carpal-pad prints only, digital-pad prints only and, in rare cases, both. The morphology of the prints is similar in arrangement and proportion to the prints of modern wombats, though some of the best preserved prints are up to 50\% larger than those of modern wombats. The average stride length for the combined trackways is $380 \mathrm{~mm}$, average trackway width $130 \mathrm{~mm}$ and average pes length $100 \mathrm{~mm}$ (Table 1). While most footprints in trackway T2 lack digital impressions, many digital impressions are discernible in trackways T4, T12 and T13 (Fig. 18). In most (pes) tracks where digital morphology is preserved, only three digits are visible. Only one (manual) print displays the impressions of all five digits (Fig. 18).
Three-digit impressions might be expected in a vombatid pes where the first digit is reduced to a small knob and the second and third digits are syndactylous (encased in a single skin sheath for most of their length). In other tracks four digits are preserved in an arrangement suggestive of a vombatid manus. The pad morphology and the dimensions of these trackways (T2, T4, T8, T12, T13 and T14; Fig. 2) are closely comparable with those measured in extant Vombatus ursinus (see Table 1) and suggest that the trackmaker was probably a large species of wombat. While the possibility that the various small-quadruped trackways were made by a modern species of Vombatus or Lasiorhinus cannot be ruled out, the size of some individual prints suggests that a larger wombat species was responsible for at least some trackways.

Where pedal digital impressions are visible, the prints are often turned inwards at an angle between $30^{\circ}$ and $40^{\circ}$ to the direction of the trackway. This degree of in-turning was not observed in the modern Vombatus tracks measured for this study, but Triggs (2004) figured Vombatus tracks where the feet are turned in to a similar degree. Farlow and Pianka (2000) observed that the degree of inturning of prints is often used to distinguish between species in ichnological studies. However, Bang (2001) noted that quadrupedal, plantigrade animals, such as bears, often walk with their feet turned slightly inwards at slow speeds while at faster speeds the feet are more forward-pointing. Lockley et al. (2002) have suggested that trackway gauge may be ontogenetically variable in 
sauropods but the possibility of print in-turning also being ontogenetically variable has apparently not been investigated.

The in-turned footprints of some vombatid trackways (e.g. T2), also made by a plantigrade animal, may therefore indicate that the animal responsible was moving at a slow speed. This is supported by the relatively short stride length. The pace angulation measured in the various small-quadruped trackways (Table 2) is also similar to that of extant wombats, the low angles measured in T2 suggesting the animal was moving relatively slowly, since the angle increases as speed increases.

We conclude that these trackways were made by several vombatids moving at a slow walk through moist sand. In the case of T12 the digits sank in further than the pads and hence left deeper impressions. In T4 a combination of digital and tarsal/carpal pad impressions was left, indicating that the sediment consistency was more favourable for preservation of the complete footprint than in most other trackways. For other vombatid trackways (T2, T8, T13 and T14), generally only an indistinct outline of the tarsal/carpal pads was preserved. For T2 on the slope of sand bar 3, the sediment was probably softer, whereas for T8, T13 and T14 on the crest of sand bar 2 , the sediment was firmer than where T4 was most faithfully formed. Most of the tracks are within the size range of modern wombat species although the presence of some larger tracks suggests that a species the size of Ramsayia magna or 'Phascolomys' medius may have been responsible for some or all of the trackways.

Because the morphology of the manus and pes of a juvenile diprotodontid is likely to have been similar to that of a wombat, it is possible that a very young diprotodontid was responsible for the "vombatid" trackways. The trackmakers would have had to be pouch young, based on the size of skeletal material from $D$. optatum pouch young collected from LakeCallabonna (SAM P10562). However, the lack in the small-quadruped trackways of any medial projection of the digits relative to the tarsus, such as is seen in the pes of Diprotodon, makes this alternative unlikely. Another possibility is that a species of Thylacoleo was responsible for some of the tracks (see below). However, one would expect the stride length of Thylacoleo to be proportionally much longer in relation to foot size than is seen in most of the trackways, as T. carnifex had proportionally longer legs than wombats.

\subsubsection{Unidentified quadruped}

One short trackway (T11) preserves two prints with four distinct digits (Figs. 2 and 19) in an arrangement similar to that left by animals with a large opposable digit such as possums (see Triggs, 2004). In both prints the digital impressions are longer than in the vombatid trackways. As wombats have relatively short digits, it seems likely that a different taxon was responsible for T11. What can be seen of the carpal pad morphology also appears to differ from that of modern vombatids. The rounded toe impressions probably represent the ungual phalangeal pads and are reminiscent of those of felids. The absence of claw marks from T11 suggests either that the prints belonged to T. carnifex and that its claws, and possibly the entire first digit, were held above the ground as the animal moved over the moist substrate; or that T. carnifex was not the trackmaker. Both Wells and Nichol (1977) and Finch and Freedman (1988) considered the manus of T. carnifex to be held in a digitigrade stance. Since the carpal pads are only partially imprinted in T11 and the digital impressions end in rounded stubs, the possibility remains that $T$. carnifex was responsible for this trackway. There is no other likely candidate in the known Pleistocene fauna for prints of this size and morphology.

\subsection{Geochronology}

None of the three geochronological techniques applied provides a closely constrained estimate of the age of the trackways. Together, however, they indicate that the trackways were formed in the interval $60-110 \mathrm{ka}$.

1. For the trackways-bearing volcaniclastic sandstone, OSL yields a minimum age of $75 \mathrm{ka}$ (Appendix 1).

2. For the matrix to the skeletal remains of skeletal accumulation 2, OSL provides a minimum age of $57 \mathrm{ka}$ (Appendix 1).

3. For teeth from skeletal accumulation 2, combined U-series/ESR analysis yields a best estimate of $98 \pm 15 \mathrm{ka}$ (Appendices 2 and 3 ).

4. For the dolomitic limestone overlying the trackways-bearing volcaniclastics, $U-T h$ dating gives a minimum age of $60 \pm 7 \mathrm{ka}$ for secondary calcite accumulation within it (Appendix 4).
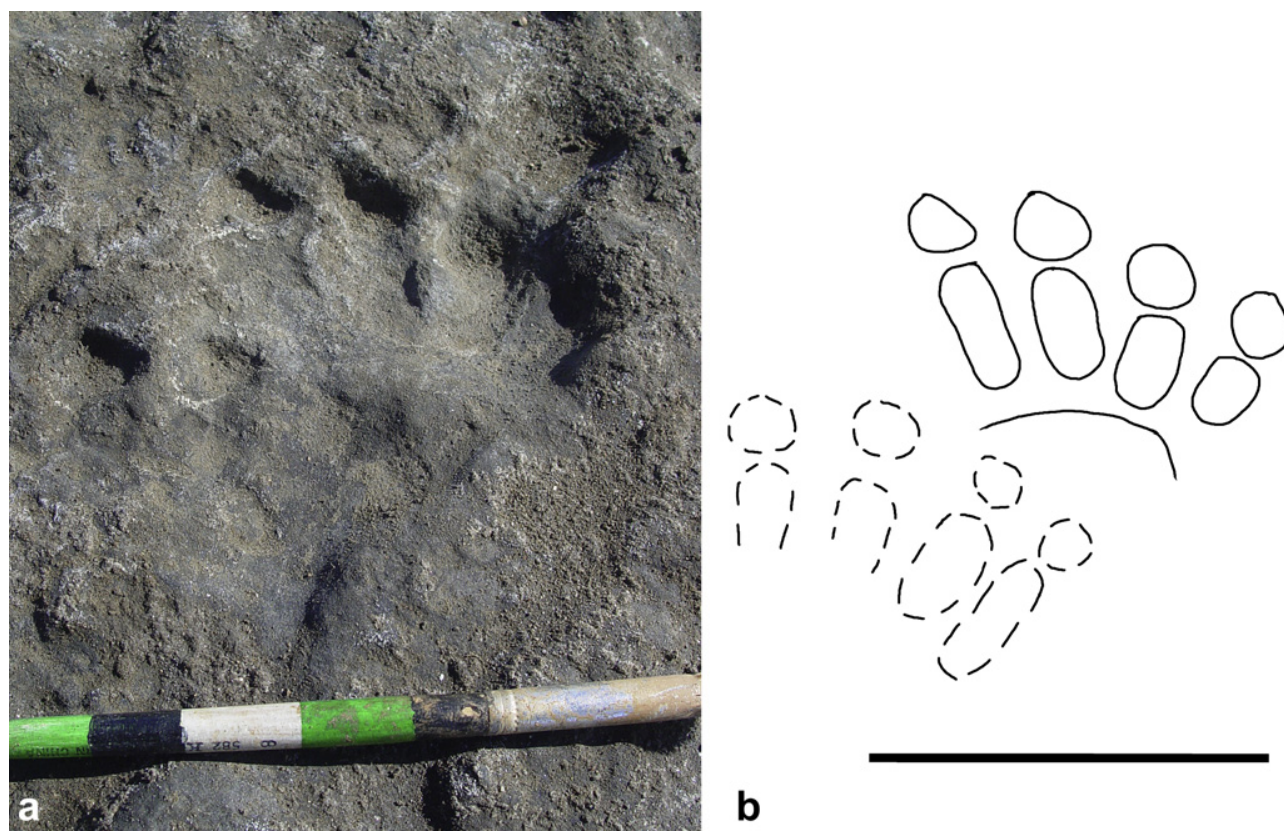

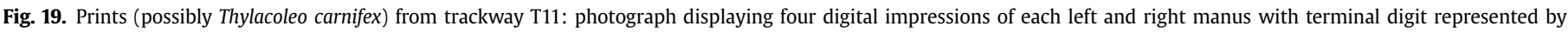
rounded pad (a); interpretation of preserved pad morphology in (a) (b). 
The $\mathrm{U}$-series results are listed in Appendix 2 and ESR results in Appendix 3. Only samples 2484 and 2487 yielded finite U-series results on the dentine, the other samples indicating uranium leaching, as expressed in ${ }^{230} \mathrm{Th} /{ }^{238} \mathrm{U}$ activity ratios larger than the equilibrium values. Leaching is not often documented in Quaternary teeth, but it seems to occur more frequently in Australian samples, perhaps because marsupials do not have a barrier to diffusion at the outside of the tooth enamel (Grün et al., 2008). This complicates any age assessments. It is likely that the other teeth also experienced $U$ loss, after an initial phase of $U$ uptake. As a result, the $U-$ series ages should be regarded as maximum age estimates. If the samples are considered of the same age, then their maximum age should be around $130 \mathrm{ka}$.

For the ESR analysis, we calculated closed system ages only, because any parametric U-uptake modelling seems nonsensical (Grün, 2009b). Indeed, all U-series results are older than the closed system ESR results, an additional indication that all samples experienced $U$ leaching. Like the $U$-series results, the closed system ESR age estimates should be regarded as maximum ages. The ESR results cluster much more tightly than the U-series data. Their average and standard deviation of $98 \pm 15$ ka provide a reasonable estimate for the maximum age of the deposit.

Two U-Th analyses of secondary carbonate within the dolomitic limestone that overlies the volcaniclastics give ages of $60 \pm 7 \mathrm{ka}$ and $53 \pm 5 \mathrm{ka}$. These date the formation of concentrations of impermeable calcite within the limestone, which is permeable in places and is too rich in Th-bearing silicate minerals to be directly dated using U-Th. Even for the secondary carbonate dated, initial Th contamination is a significant problem and has led to unusually large age uncertainties of $\sim 10 \%$. A third sample was less pure and consequently less precise ( $45 \pm 20 \mathrm{ka}$ ), but confirms that the chosen initial ${ }^{230} \mathrm{Th} /{ }^{232} \mathrm{Th}$ range is broadly correct. The slight scatter in reported ages may reflect variation in the age of the secondary calcite accumulations dated, and we take the oldest of our three age determinations as a minimum age for the limestone itself.

In combination, the several estimates point to an age in the range 60-110 ka for the trackways. The preferred age for the overlying carbonate unit is essentially identical to the youngest estimate for the trackway-bearing volcaniclastics. Thus, the carbonate unit may have buried the trackways surface virtually immediately following the formation of the trackways, as would be expected from the fine preservation of the latter.

\section{Discussion}

\subsection{Palaeoenvironment}

It has been suggested that the environments most conducive to footprint preservation are lake and river margins (Cohen et al., 1993; Mustoe, 2002). The VVP trackways exposure is at the edge of a modern lake and, although the configuration of the lake is probably vastly changed since the trackways formed, the sedimentological evidence strongly supports a lacustrine setting for the host sediments. First- and second-order bed forms (parallel sand bars and ripples) are aqueous in origin, formed at the western margin of the Pleistocene lake. The numerous erosional scours, some with associated mini-deltas, indicate at least intermittent exposure of the sand bars and suggest that they might be swash bars. The western side is the windward margin of the modern lake, and there is no reason to think that the wind regime was markedly different in the Pleistocene (Hesse, 1994). The presence of bars on the western side is therefore anomalous but may be explained by occasional strong easterlies.

Near-freshwater conditions when the trackmakers were active were replaced by high salinities that led to the deposition of the upper unit, the dolomitic limestone. Similar carbonate rocks are forming in many modern saline lakes in the VVP (De Deckker and Last, 1989; Gell et al., 1994; E.B. Joyce, personal communication, 2007).

\subsection{Sediment sources, lower unit}

The abundant volcanic component (glass, mafic minerals, plagioclase) of the sandstone derives from basaltic tuffs of the Newer Volcanic Group, erupted from one or more of the many maars and small cones of the region. Most of the quartz is likely to have come from the Black Rock Sandstone, a Pliocene deposit that is widespread across southern Victoria and which underlies the Newer Volcanic Group (VandenBerg, 2009). Underlying the Black Rock Sandstone, and providing the probable source of reddened calcareous foraminifers, is the Gellibrand Marl (OligoceneMiocene). Such marine fossils were most likely brought to the surface by maar eruptions. Grains of iron oxide were probably eroded from the weathering zone. The VVP lack an integrated drainage system and sediment tends to accumulate in lake basins.

\subsection{Palaeobiological implications}

Species found in various skeletal fossil deposits in the south-east of Australia and potentially represented by trackways in the VVP include: D. optatum, Z. trilobus, Ramsayia magna, 'Phascolomys' medius, Vombatus ursinus, Lasiorhinus krefftii, Thylacoleo carnifex, M. giganteus, M. rufus, Protemnodon anak, P. brehus and P. roechus (Prideaux, 2006). For the reasons outlined above we narrow the list of possible trackmakers at this site to D. optatum, R. magna (or 'Phascolomys' medius), V. ursinus, L. krefftii, Protemnodon sp. and T. carnifex.

The variability in footprint preservation seen in the D. optatum trackway (T1) suggests variation in sediment saturation or even that some tracks were formed under water. Differences in footprint spacing indicate that the individual responsible for the trackway was moving at different speeds along different parts of the trackway. The greatest degree of sediment distortion is seen at the start of the trackway, on sand bar 1 (the area of the trackway with greatest variability in topography), where the footprint spacing indicates the animal was moving relatively slowly. The part of the trackway where the manus and pes prints overlap strongly (indicating increased speed) includes the two footprints with contiguous splash marks (ejecta) (Fig. 9). The ejecta are a result of liquefaction of moist sediment beneath the animal's feet. The distal segment of T1, consisting of poorly defined tracks, was imprinted in saturated sediment, possibly under water. The degree of saturation increased distally along the trackway as the surface elevation decreased.

The gauge of the D. optatum trackway (T1) at this site, when compared with the D. optatum tracks at Lake Callabonna (made by an individual of similar size moving at a similar speed), indicates that this species was capable of varying trackway gauge significantly depending on substrate. This may be the first instance where a factor other than speed (e.g. Day et al., 2002) has been identified as causing intraspecific variation in trackway gauge. Such variation calls into question the utility of trackway gauge in distinguishing amongst marsupial trackmakers, despite this parameter's commonly being used to differentiate dinosaurian ichnospecies (e.g. Farlow and Pianka, 2000). In fact, the use of trackway gauge in distinguishing vertebrate species in general must be considered questionable.

When the defining characteristic of marsupials, the presence of a pouch, is taken into account, sexual dimorphism might be expected to be another source of variation in trackway gauge. 
Presumably the presence of a large pouch young would prevent a female Diprotodon from walking with the hindlimbs directly under the body and would force them to be held further apart. The trackway gauge disparity between the Callabonna Diprotodon trackways and the VVP Diprotodon trackways may thus indicate that the latter trackmaker was a female with a pouch young. The paucity of fossil trackways made by marsupials has meant that the possibility of sexual dimorphism in these trackways has not previously been considered. However, it would not be surprising if it were shown that sexual dimorphism existed in the gait of all large-bodied, quadrupedal marsupials. Sexual dimorphism has previously been suggested to have occurred in archosaur (Tresise, 1996; Avanzini and Lockley, 2002) and dinosaur (Dodson, 1976; Irby, 1995; Galton and Farlow, 2003) trackways but is represented by differences in footprint morphology and size rather than trackway gauge. We have not found any other accounts of sexual dimorphism in a fossil mammalian trackway.

\subsection{Preservation}

In general, the faithfulness of the mould of an indenter (e.g. a foot) is a reflection of the host sediment's grain size, cohesiveness and water saturation (Allen, 1997; Milàn, 2006). In an experimental study, Jackson et al. (2009) found that the best print formation took place in moist sand rather than in dry or saturated sand. The lack of morphological detail in some of the prints described here may be because the sediment was too cohesive to take a complete print (the print was unformed or only partially formed) or because the sediment was too saturated to preserve details of the pad morphology. The preservation of some digital morphology suggests rapid burial after drying and hardening of the host matrix.

At the VVP locality, there are three additional factors that were integral to the formation and preservation of the trackways:

- the likely presence in the original unconsolidated volcaniclastic sand of a small amount of smectite clay;

- the impregnation of the uppermost centimetre of the volcaniclastic sandstone with calcitic cement, together with the localised precipitation of a calcite crust upon the trackways surface; and

- burial of the volcaniclastic sandstone and the trackways surface by the overlying dolomitic limestone.

A very small proportion $(<1 \%)$ of smectite clay has been shown to cause a marked increase in the cohesion of sand and the preservability of footprints in sand (Loope, 1986). XRD analysis (Fig. 4) shows the abundance of smectite to be $4-8 \%$ in a sample of the volcaniclastic sandstone. Smectite is a minor weathering product of some of the widespread basalt of the VVP (Briner and Jackson, 1970; Mokma et al., 1973; J. Webb pers. comm., 2009). While a portion of the smectite in the analysis may derive from post-depositional weathering of the sandstone, it is likely that some smectite clay was a component of the sediment at the time the trackways were formed.

Much, though not all, of the exposed trackways-bearing surface is indurated with a calcitic cement that disappears at about $1 \mathrm{~cm}$ below the surface. In places, a calcitic crust, a millimetre or two thick, coats the upper surface of the volcaniclastic sandstone. The excellent preservation of many of the trackways suggests that precipitation of the cement began very soon after trackway formation. Further, (i) preservation of some tracks as plugs and (ii) burial of the distal portion of $\mathrm{T} 2$ beneath clinoformal bedding point to the former presence of a protective thin layer of volcaniclastic sand over the trackway surface for some undefined period in the past.
Although now partially stripped, the dolomitic limestone (the upper unit) probably formed a continuous cover, $10-15 \mathrm{~cm}$ thick, upon the volcaniclastic sandstone and the trackways surface. The geochronology permits a gap between trackways formation and carbonate deposition of anything between zero and some tens of thousands of years. It is easiest to explain the excellent preservation of the trackways if the gap were very short.

\section{Conclusion}

The VVP assemblage of Pleistocene trace fossils is the taxonomically most diverse group of marsupial trackways known. In addition to diprotodontid, macropodid, vombatid and possible thylacoleonid trackways, the locality also yields trace fossils of invertebrates and plants. Well preserved sedimentary features show that the trackmakers were attracted to a lake which, at some time after the formation of the trackways, changed from near-fresh to saline. The diprotodontid, if correctly identified as $D$. optatum, was travelling at a rate of about $5 \frac{1}{2} \mathrm{~km} / \mathrm{h}\left(1 \frac{1}{2} \mathrm{~ms}^{-1}\right)$ into the waters of the lake. Most other animals were moving parallel to the inferred shoreline. The trackmakers were active at some time in the interval 60-110 ka. Preservation was a function of the primary mineralogy of the sediment, the penecontemporaneous formation of a calcite crust and the subsequent burial beneath a dolomitic limestone when the lake turned saline.

\section{Acknowledgements}

We thank an anonymous farming family of the Victorian Volcanic Plains who have protected the trackways for decades; Parks Victoria staff, especially John Clarke, Frank Gleeson, Dave Jenson and Rob Wallis; Peter Swinkels and his crew of preparators from Museum Victoria who moulded major sections of the trackways; students, staff and friends of the University of Ballarat and DAP's crew of volunteers who helped lay out the grid, measure the tracks and excavate the skeletal fossils; and Matt Gibson of the University of Ballarat who prepared the map of the locality. We appreciate discussions with Steven Bourne (Naracoorte Caves World Heritage Site), Peter Dahlhaus (University of Ballarat), Bernie Joyce (University of Melbourne), John Long (formerly Museum Victoria), Tony Martin (Emory University), Wayne Stephenson (University of Melbourne), Barbara Triggs, Fons VandenBerg (Geoscience Victoria), John Webb (La Trobe University) and Rod Wells (Flinders University). The editor, Colin Murray-Wallace, and the journal reviewers, including Gavin Prideaux (Flinders University), helped considerably to improve the manuscript. Aspects of this study were funded by the Corangamite Catchment Management Authority and Heritage Australia, and through ARC DP0664144. John Long, then of Museum Victoria, provided funding for the moulding of the trackways, with a cast of part of the diprotodontid trackway being incorporated into the new permanent exhibition at Museum Victoria, 600 Million Years - Victoria Evolves. Kim Dowling and Stephanie Davison secured finance for the University of Ballarat's set of casts; and Alan Kealy documented part of the work with still and motion cameras. RG is grateful to the Institut des Sciences humaines et sociales du CNRS, Bordeaux, and the Laboratoire d'Anthropologie des populations du Passé, Université de Bordeaux I, for their kind hospitality in the writing-up stage of this manuscript. We acknowledge Amy Toensing whose photograph of the diprotodontid trackway in National Geographic (October, 2010) shows how art can enhance science. SPC dedicates this paper to the memory of Jack Douglas, geologist and palaeobotanist, on the day of whose funeral he first saw the trackways. 


\section{Appendix 1}

Optically stimulated luminescence data and optical age estimates from megafaunal trackways locality, Victorian Volcanic Plains.

\begin{tabular}{|c|c|c|c|c|c|c|c|c|c|c|c|}
\hline $\begin{array}{l}\text { Depth } \\
(\mathrm{m})\end{array}$ & Water $^{\mathrm{a}}(\%)$ & $\mathrm{K}(\%)$ & $\begin{array}{l}\text { Th } \\
(\mathrm{ppm})\end{array}$ & $\begin{array}{l}\mathrm{U} \\
(\mathrm{ppm})\end{array}$ & $\begin{array}{l}a \text { radiation } \\
\left(\mathrm{Gy} \mathrm{ka}^{-1}\right)\end{array}$ & $\begin{array}{l}b \text { radiation }^{\mathrm{c}} \\
\left(\mathrm{Gy} \mathrm{ka}^{-1}\right)\end{array}$ & 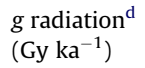 & $\begin{array}{l}\text { Cosmic-ray radiation } \\
\left(\mathrm{Gy} \mathrm{ka}^{-1}\right)\end{array}$ & $\begin{array}{l}\text { Total dose rate } \\
\left(\mathrm{Gy} \mathrm{ka}^{-1}\right)\end{array}$ & $\begin{array}{l}\text { Equivalent } \\
\text { dose }^{f}(G y)\end{array}$ & $\begin{array}{l}\text { Optical age } \\
\text { (ka) }\end{array}$ \\
\hline 0.15 & $30 \pm 6$ & $1.00 \pm 0.07$ & $7.24 \pm 0.37$ & $1.28 \pm 0.09$ & $0.03 \pm 0.01$ & $0.79 \pm 0.06$ & $0.57 \pm 0.04$ & $0.28 \pm 0.03$ & $1.66 \pm 0.11$ & $>96$ & $>57$ \\
\hline 0.15 & $30 \pm 6$ & $0.91 \pm 0.08$ & $9.60 \pm 0.43$ & $1.89 \pm 0.10$ & $0.03 \pm 0.01$ & $0.93 \pm 0.07$ & $0.56 \pm 0.04$ & $0.28 \pm 0.03$ & $1.79 \pm 0.12$ & $>136$ & $>75$ \\
\hline
\end{tabular}

a Estimated time-averaged moisture contents, based on measured field water values (\% dry weight).

b Assumed internal alpha dose rate.

c Derived from INAA radionuclide concentration measurements using the conversion factors of Adamiec and Aitken (1998), corrected for attenuation by water and beta attenuation.

d Derived from field gamma spectrometry measurements using the conversion factors of Adamiec and Aitken (1998), corrected for attenuation by water.

e Dalculated using the equation of Prescott and Hutton (1994), based on sediment density, time-averaged depth and site latitude, longitude and altitude.

${ }^{\mathrm{f}}$ Including a $\pm 2 \%$ systematic uncertainty associated with calibration of the laboratory beta-source.

Appendix 2

U-series results from laser scanning of macropodid teeth from skeletal accumulation 2, VVP trackways locality.

\begin{tabular}{|c|c|c|c|c|}
\hline Sample & $\mathrm{U}(\mathrm{ppm})$ & ${ }^{230} \mathrm{Th} /{ }^{238} \mathrm{U}$ & ${ }^{234} U /{ }^{238} U$ & Age (ka) \\
\hline $2483 \mathrm{EN}$ & $1.30 \pm 0.13$ & & & \\
\hline $2483 \mathrm{DE}$ & $26.92 \pm 1.78$ & $1.0657 \pm 0.0899$ & $1.0784 \pm 0.0165$ & $360_{-130}^{+\infty}$ \\
\hline $2484 \mathrm{EN}$ & $1.00 \pm 0.07$ & & & \\
\hline $2484 \mathrm{DE}$ & $3.75 \pm 0.26$ & $0.8303 \pm 0.0809$ & $1.0686 \pm 0.0317$ & $159_{-32}^{+43}$ \\
\hline $2485 \mathrm{EN}$ & $1.57 \pm 0.51$ & $1.2664 \pm 0.1787$ & $1.4408 \pm 2086$ & $188_{-71}^{+194}$ \\
\hline $2485 \mathrm{DE}$ & $21.38 \pm 0.37$ & $1.2916 \pm 0.0579$ & $1.0595 \pm 0.0201$ & Leaching \\
\hline $2485 \mathrm{EN}$ & $0.69 \pm 0.12$ & & & \\
\hline $2486 \mathrm{DE}$ & $24.6 \pm 1.29$ & $1.2639 \pm 0.0519$ & $1.0546 \pm 0.0138$ & Leaching \\
\hline $2486 \mathrm{EN}$ & $0.15 \pm 0.02$ & & & \\
\hline $2487 \mathrm{EN}$ & $0.26 \pm 0.03$ & & & \\
\hline $2487 \mathrm{DE}$ & $28.5 \pm 1.68$ & $0.6411 \pm 0.0388$ & $0.9263 \pm 0.0199$ & $131_{-16}^{+19}$ \\
\hline $2487 \mathrm{EN}$ & $0.23 \pm 0.03$ & & & \\
\hline
\end{tabular}

Appendix 3

ESR results from macropodid teeth from skeletal accumulation 2, VVP trackways locality.

\begin{tabular}{|c|c|c|c|c|c|c|c|c|c|c|c|}
\hline \multirow[t]{2}{*}{ Sample } & $\mathrm{D}_{\mathrm{e}}$ & Thickness & U-SED & Th-SED & K-SED & $\gamma$, cosmic DR & $\beta$-DR & Int. DR & DE-DR & Total DR & Age \\
\hline & (Gy) & $(\mu \mathrm{m})$ & (ppm) & (ppm) & $(\%)$ & $(\mu \mathrm{Gy} / \mathrm{a})$ & $(\mu \mathrm{Gy} / \mathrm{a})$ & $(\mu \mathrm{Gy} / \mathrm{a})$ & $(\mu \mathrm{Gy} / \mathrm{a})$ & $(\mu \mathrm{Gy} / \mathrm{a})$ & (ka) \\
\hline $2483 \mathrm{~A}$ & $163 \pm 9$ & 1140 & 0.92 & 7.09 & 1.27 & $785 \pm 66$ & $96 \pm 13$ & $363 \pm 60$ & $269 \pm 34$ & $1513 \pm 97$ & $107 \pm 9$ \\
\hline 2483B & $169 \pm 10$ & 780 & 0.92 & 7.09 & 1.27 & $785 \pm 66$ & $13 \pm 20$ & $344 \pm 58$ & $406 \pm 46$ & $1672 \pm 102$ & $101 \pm 8$ \\
\hline $2484 \mathrm{~A}$ & $159 \pm 10$ & 1180 & 14.99 & 4.36 & 1.66 & $1330 \pm 131$ & $174 \pm 24$ & $259 \pm 41$ & $39 \pm 4$ & $1802 \pm 140$ & $88 \pm 8$ \\
\hline 2484B & $150 \pm 13$ & 1140 & 14.99 & 4.36 & 1.66 & $1330 \pm 131$ & $179 \pm 25$ & $253 \pm 39$ & $39 \pm 4$ & $1801 \pm 139$ & $83 \pm 9$ \\
\hline 2485 & $173 \pm 10$ & 920 & 5.79 & 8.65 & 2.41 & $1100 \pm 103$ & $271 \pm 37$ & $270 \pm 48$ & $276 \pm 26$ & $1917 \pm 123$ & $90 \pm 7$ \\
\hline $2486 \mathrm{~A}$ & $213 \pm 16$ & 840 & 3.80 & 6.88 & 2.29 & $981 \pm 89$ & $250 \pm 35$ & $43 \pm 10$ & $377 \pm 38$ & $1651 \pm 104$ & $129 \pm 12$ \\
\hline $2486 B$ & $164 \pm 6$ & 1000 & 3.80 & 6.88 & 2.29 & $981 \pm 89$ & $213 \pm 29$ & $41 \pm 8$ & $311 \pm 31$ & $1546 \pm 99$ & $106 \pm 7$ \\
\hline $2487 A$ & $143 \pm 6$ & 1180 & 4.88 & 6.99 & 2.22 & $1020 \pm 94$ & $190 \pm 23$ & $65 \pm 15$ & $299 \pm 29$ & $1574 \pm 103$ & $90 \pm 7$ \\
\hline 2487B & $137 \pm 5$ & 1100 & 4.88 & 6.99 & 2.22 & $1020 \pm 94$ & $205 \pm 27$ & $63 \pm 16$ & $313 \pm 31$ & $1601 \pm 104$ & $85 \pm 6$ \\
\hline
\end{tabular}

\section{Appendix 4}

U-Th isotopic data and calculated ages for three samples of lacustrine dolomitic limestone, VVP trackways locality. Subsamples of $\sim 10$ mg of the purest available

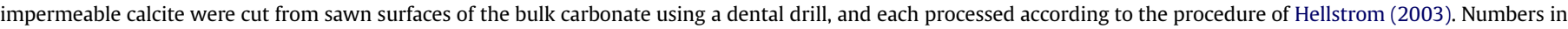

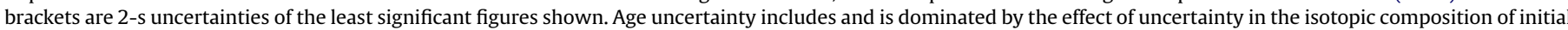
(detrital) thorium.

\begin{tabular}{|c|c|c|c|c|c|c|c|c|}
\hline Sample & Lab no. \& date & $\mathrm{U}\left(\mathrm{ngg}^{-1}\right)$ & {$\left[{ }^{230} \mathrm{Th} /{ }^{238} \mathrm{U}\right]^{\mathrm{a}}$} & {$\left[{ }^{234} U / /^{238} U\right]^{a}$} & {$\left[{ }^{232} \mathrm{Th} /{ }^{238} \mathrm{U}\right]$} & {$\left[{ }^{230} \mathrm{Th} /{ }^{232} \mathrm{Th}\right]$} & Age $^{\mathrm{b}}$ & {$\left[{ }^{234} \mathrm{U} /{ }^{238} \mathrm{U}\right]_{\mathrm{i}}^{\mathrm{c}}$} \\
\hline Trackway-1 & UMA01951 Jan-2008 & 883 & $0.7293(26)$ & $1.4346(27)$ & $0.1776(018)$ & 4.11 & $60(07)$ & $1.516(11)$ \\
\hline Trackway-2 & UMA02150 Aug-2008 & 899 & $0.6484(45)$ & $1.4422(30)$ & $0.1288(011)$ & 5.03 & $53(05)$ & $1.514(08)$ \\
\hline LM-07-17 & UMA02615 Mar-2009 & 1239 & $0.7275(26)$ & $1.3701(25)$ & $0.3798(204)$ & 1.92 & $45(20)$ & $1.421(24)$ \\
\hline
\end{tabular}

a Activity ratios determined after Hellstrom (2003) using the decay constants of Cheng et al. (2000).

b Age in kyr before present corrected for intial ${ }^{230} \mathrm{Th}$ using eqn. (1) of Hellstrom (2006) and $\left[{ }^{230} \mathrm{Th} /{ }^{232} \mathrm{Th}\right]_{\mathrm{i}}$ of $1.0 \pm 0.5$.

${ }^{c}$ Initial $\left[{ }^{234} \mathrm{U} /{ }^{238} \mathrm{U}\right]$ calculated using corrected age. 


\section{References}

Adamiec, G., Aitken, M.J., 1998. Dose-rate conversion factors: update. Ancient TL 16, $37-50$.

Aitken, M.J., Clark, P.A., Gaffney, C.F., Lovborg, L., 1985. Beta and gamma gradients. Nuclear Tracks 10, 647-653.

Alexander, R.M., 1976. Estimates of speeds of dinosaurs. Nature 261, 129-130.

Alexander, R.M., 1984. The gaits of bipedal and quadrupedal animals. The International Journal of Robotic Research 3, 49-59.

Allen, J.R.L., 1989. Fossil vertebrate tracks and indenter mechanics. Journal of the Geological Society of London 146, 600-602.

Allen, J.R.L., 1997. Subfossil mammalian tracks (Flandrian) in the Severn Estuary, S.W. Britain: mechanics of formation, preservation and distribution. Philosophical Transactions of the Royal Society of London B 352, 481-518.

Ataabadi, M.M., Sarjeant, W.A.S., 2000. Eocene mammal footprints from eastern Iran: a preliminary study. Comptes Rendus de l'Académie des Sciences, Series IIA, Earth and Planetary Science 331, 543-547.

Avanzini, M., Lockley, M., 2002. Middle Triassic archosaur population structure: interpretation based on Isochirotherium delicatum fossil footprints (Southern Alps, Italy). Palaeogeography, Palaeoclimatology, Palaeoecology 185, 391-402.

Bang, P., 2001. Animal Tracks and Signs. Oxford University Press, Oxford.

Belperio, A.P., Fotheringham, D.G., 1990. Geological setting of two Quaternary footprint sites, western South Australia. Australian Journal of Earth Sciences 37, 37-42.

Briner, G.P., Jackson, M.L., 1970. Mineralogical analysis of clays in soils developed from basalts in Australia. Israel Journal of Chemistry 8, 487-500.

Camens, A.B., Wells, R.T., 2009. Diprotodontid footprints from the Pliocene of central Australia. Journal of Vertebrate Paleontology 29, 863-869.

Cheng, H., Edwards, R.L., Hoff, J., Gallup, C.D., Richards, D.A., Asmerom, Y., 2000. The half-lives of uranium-234 and thorium-230. Chemical Geology 169, 17-33.

Cohen, A.S., Halfpenny, J., Lockley, M., Michel, E., 1993. Modern vertebrate tracks from Lake Manyara, Tanzania and their paleobiological implications. Paleobiology 19, 433-458.

Day, J.J., Norman, D.B., Upchurch, P., Powell, H.P., 2002. Dinosaur locomotion from a new trackway. Nature 415, 494-495.

De Deckker, P., Last, W.M., 1989. Modern, non-marine dolomite in evaporitic playas of western Victoria, Australia. Sedimentary Geology 64, 223-238.

Dodson, P., 1976. Quantitative aspects of relative growth and sexual dimorphism in Protoceratops. Journal of Paleontology 50, 929-940.

Eggins, S., Grün, R., Pike, A., Shelley, A., Taylor, L., 2003. ${ }^{238} \mathrm{U},{ }^{232} \mathrm{Th}$ profiling and $\mathrm{U}$-series isotope analysis of fossil teeth by laser ablation-ICPMS. Quaternary Science Reviews 22, 1373-1382.

Eggins, S., Grün, R., McCulloch, M., Pike, A., Chappell, J., Kinsley, L., Shelley, M., Murray-Wallace, C., Spötl, C., Taylor, L., 2005. In situ U-series dating by laserablation multi-collector ICPMS: new prospects for Quaternary geochronology Quaternary Science Reviews 24, 2523-2538.

Farlow, J.O., Gatesy, S.M., Holts, T.R., Hutchinson, J.R., Robinson, J.M., 2000. Theropod locomotion. American Zoologist 40, 640-663.

Farlow, J.O., Pianka, E.R., 2000. Body form and trackway pattern in Australian desert monitors (Squamata: Varanidae): comparing zoological and ichnological diversity. Palaios 15, 235-247.

Finch, M.E., Freedman, L., 1988. Functional morphology of the limbs of Thylacoleo carnifex Owen (Thylacoleonidae: Marsupialia). Australian Journal of Zoology 36 251-272.

Fornós, J.J., Bromley, R.G., Clemmensen, R.B., Rodriguez-Perea, A., 2002. Tracks and trackways of Myotragus balearicus Bate (Artiodactyla, Caprinae) in Pleistocene aeolianites from Mallorca (Balearic Islands, western Mediterranean). Palaeogeography, Palaeoclimatology, Palaeoecology 180, 277-313.

Galbraith, R.F., Roberts, R.G., Laslett, G.M., Yoshida, H., Olley, J.M., 1999. Optical dating of single and multiple grains of quartz from Jinmium rock shelter northern Australia: part I, experimental design and statistical models. Archaeometry 41, 339-364.

Galton, P.M., Farlow, J.O., 2003. Dinosaur State Park, Connecticut, USA: history, footprints, trackways, exhibits. Zubia 21, 129-173.

Gell, P.A., Barker, P.A., De Deckker, P., Last, W.M., Jelicic, L., 1994. The Holocene history of West Basin Lake, Victoria, Australia; chemical changes based on fossil biota and sediment mineralogy. Journal of Paleolimnology 12, 235-258.

Grün, R., 2002. ESR dose estimation on fossil tooth enamel by fitting the natural spectrum into the irradiated spectrum. Radiation Measurements 35, 87-93.

Grün, R., 2009a. The DATA program for the calculation of ESR age estimates on tooth enamel. Quaternary Geochronology 4, 231-232.

Grün, R., 2009b. The relevance of parametric U-uptake models in ESR age calculations. Radiation Measurements 44, 472-476.

Grün, R., Katzenberger-Apel, O., 1994. An alpha irradiator for ESR dating. Ancient TL $12,35-38$.

Grün, R., Wells, R.T., Eggins, S., Spooner, N., Aubert, M., Brown, L., Rhodes, E., 2008 Electron spin resonance dating of South Australian megafauna sites. Australian Journal of Earth Sciences 55, 917-935.

Hellstrom, J., 2003. Rapid and accurate U/Th dating using parallel ion-counting multicollector ICP-MS. Journal of Analytical Atomic Spectrometry 18, 1346-1351.

Hellstrom, J., 2006. U-Th dating of speleothems with high initial ${ }^{230} \mathrm{Th}$ using stratigraphical constraint. Quaternary Geochronology 1, 289-295.

Hesse, P.P., 1994. The record of continental dust from Australia in Tasman Sea sediments. Quaternary Science Reviews 13, 257-272.
Henderson, D.M., 2006. Simulated weathering of dinosaur tracks and the implications for their characterization. Canadian Journal of Earth Sciences 43, 691-704.

Irby, G.V., 1995. Posterolateral markings on dinosaur tracks, Cameron Dinosaur Tracksite, lower Jurassic Moenave formation, northeastern Arizona. Journal of Paleontology 69, 779-784.

Jackson, S.M., Whyte, M.A., Romano, M., 2009. Laboratory-controlled simulations of dinosaur footprints in sand: a key to understanding vertebrate track formation and preservation. Palaios 24, 222-238.

Kardong, K.V., 2002. Vertebrates: comparative Anatomy, Function, Evolution. McGraw-Hill, New York.

Laporte, L.F., Behrensmeyer, A.K., 1980. Tracks and substrate reworking by terrestrial vertebrates in Quaternary sediments of Kenya. Journal of Sedimentary Petrology 50, 1337-1346.

Lea, P.D., 1996. Vertebrate tracks in Pleistocene eolian sand-sheet deposits of Alaska. Quaternary Research 45, 226-240.

Leakey, M.D., Hay, R.L., 1979. Pliocene footprints in the Laetolil beds at Laetoli, northern Tanzania. Nature 278, 317-323.

Lockley, M.G., 1986a. The palaeobiological and palaeoenvironmental importance of dinosaur footprints. Palaios 1, 37-47.

Lockley, M.G., 1986b. A Guide to Dinosaur Tracksites of the Colorado Plateau and American Southwest. University of Colorado Geology Department, Denver. 56 pp.

Lockley, M.G., 1991. Tracking Dinosaurs: A New Look at an Ancient World. Cambridge University Press, Cambridge.

Lockley, M.G., 1998. The vertebrate track record. Nature 396, 429-432.

Lockley, M.G., Ritts, B.D., Leonardi, G., 1999. Mammal track assemblages from the Early Tertiary of China, Peru, Europe and north America. Palaios 14, 398-404.

Lockley, M., Meyer, C., 2000. Dinosaur Tracks and Other Fossil Footprints of Europe. Columbia University Press, New York.

Lockley, M., Wright, J., White, D., Matsukawa, M., Jianjun, L., Lu, F., Hong, L., 2002. The first sauropod trackways from China. Cretaceous Research 23, 363-381.

Long, J., Archer, M., Flannery, T., Hand, S., 2002. Prehistoric Mammals of Australia and New Guinea: One Hundred Million Years of Evolution. University of NSW Press, Sydney.

Loope, D.B., 1986. Recognizing and utilizing vertebrate tracks in cross section: Cenozoic hoofprints from Nebraska. Palaios 1, 141-151.

Marsh, R.E., 1999. Beta-gradient isochrons using electron paramagnetic resonance: towards a new dating method in archaeology. MSc thesis, McMaster University, Hamilton, Canada.

Mietto, P., Avanzini, M., Rolandi, G., 2003. Human footprints in Pleistocene volcanic ash. Nature 422,133

Milàn, J., 2006. Variations in the morphology of emu (Dromaius novaehollandiae) tracks reflecting differences in walking pattern and substrate consistency: ichnotaxonomic implications. Palaeontology 49, 405-420.

Mokma, D.L., Jackson, M.L., Syers, J.K., Gibbons, F.R., 1973. Mineralogy and radioisotope retention properties of a chronosequence of soils developed in basalts of Victoria, Australia. Journal of Soil Science 24, 199-214.

Murie, O.J., 1954. A Field Guide to Animal Tracks. Houghton Mifflin Company, Boston, MA.

Murray, P.F., 1991. The Pleistocene megafauna of Australia. In: Vickers-Rich, P. Monaghan, J.M., Baird, R.F., Rich, T.H. (Eds.), Vertebrate Palaeontology of Australasia. Pioneer Design Studio, Melbourne, VIC, pp. 1071-1164.

Murray, A.S., Roberts, R.G., 1998. Measurement of the equivalent dose in quartz using a regenerative-dose single-aliquot protocol. Radiation Measurements 29 503-515.

Murray, A.S., Wintle, A.G., 2000. Luminescence dating of quartz using an improved single-aliquot regenerative-dose protocol. Radiation Measurements $32,57-73$.

Mustoe, G.E., 2002. Eocene bird, reptile and mammal tracks from the Chuckanut Formation, northwest Washington. Palaios 17, 403-413.

Prescott, J.R., Hutton, J.T., 1988. Cosmic ray and gamma ray dosimetry for TL and ESR. Nuclear Tracks and Radiation Measurement 14, 223-227.

Prescott, J.R., Hutton, J.T., 1994. Cosmic ray contributions to dose rates for luminescence and ESR dating: large depths and long-term time variations. Radiation Measurements 23, 497-500.

Prideaux, G.J., 2006. Mid-Pleistocene vertebrate records: Australia. In: Elias, S.A. (Ed.), Encyclopedia of Quaternary Science. Elsevier, London, pp. $1517-1537$.

Price, G.J., 2008. Taxonomy and palaeobiology of the largest-ever marsupial, Diprotodon, Owen, 1838 (Diprotodontidae, Marsupialia). Zoological Journal of the Linnean Society 153, 369-397.

Quigley, M.C., Cupper, M.L., Sandiford, M., 2006. Quaternary faults of south-central Australia: palaeoseismicity, slip rates and origin. Australian Journal of Earth Sciences 53, 285-301.

Richards, D.A., Dorale, J.A., 2003. Uranium-series chronology and environmental applications of speleothems. Reviews in Mineralogy \& Geochemistry 52, 407-460.

Scott, H.H., 1915. A monograph of Nototherium tasmanicum. Geological Survey Record 4, Tasmania Department of Mines.

Scott, H.H., Lord, C.E., 1920a. Studies in Tasmanian mammals living and extinct. Number I. Nototherium mitchelli (a marsupial rhinoceros). Papers and Proceedings of the Royal Society of Tasmania 1920, 13-15.

Scott, H.H., Lord, C.E., 1920b. Studies in Tasmanian mammals living and extinct. Number III. Nototherium mitchelli. Its evolutionary trend-the skull, and such 
structures as related to the nasal horn. Papers and Proceedings of the Royal Society of Tasmania 1920, 76-96.

Scott, H.H., Lord, C.E., 1920c. Studies in Tasmanian mammals living and extinct. Number IV. Nototherium mitchelli. Appendicular skeleton, including the manus and pes (hitherto unknown). Papers and Proceedings of the Royal Society of Tasmania 1920, 97-113.

Stirton, R.A., 1963. A review of the macropodid genus Protemnodon. University of California Publications in Geological Sciences 44 (2), 97-162.

Stossel, I., 1995. The discovery of a new Devonian tetrapod trackway in SW Ireland. Journal of the Geological Society of London 152, 407-413.

Tedford, R.H., 1973. The diprotodons of Lake Callabonna. Australian Natural History 17, 349-354.

Thulborn, R.A., 1989. The gaits of dinosaurs. In: Gillette, D.D., Lockley, M.G. (Eds.), Dinosaur Tracks and Traces. Cambridge University Press, New York.

Thulborn, T., 1990. Dinosaur Tracks. Chapman and Hall, Melbourne.

Thulborn, R.A., Wade, M., 1984. Dinosaur trackways in the Winton Formation (midCretaceous) of Queensland. Memoirs of the Queensland Museum 21, 413-517.
Tresise, G., 1996. Sex in the footprint bed. Geology Today 12, 22-26.

Triggs, B., 2004. Tracks, Scats and Other Traces: a Field Guide to Australian Mammals. Oxford University Press, Melbourne, VIC, 340 pp.

VandenBerg, A.H.M., 2009. Rock unit names in the Bendigo Zone portion of central Victoria, Seamless Geology project. Geological Survey of Victoria Report 129, 112.

Webb, S., Cupper, M.L., Robins, R., 2006. Pleistocene human footprints from the Willandra Lakes, southeastern Australia. Journal of Human Evolution 50 405-413.

Weisbecker, V., Archer, M., 2008. Parallel evolution of hand anatomy in kangaroos and vombatiform marsupials: functional and evolutionary implications. Palaeontology 51, 321-338.

Wells, R.T., Nichol, B., 1977. On the manus and pes of Thylacoleo carnifex Owen (Marsupialia). Transactions of the Royal Society of South Australia 101,139-146

Wells, R.T., Tedford, R.H., 1995. Sthenurus (Macropodidae: Marsupialia) from the Pleistocene of Lake Callabonna, South Australia. In: Bulletin of the American Museum of Natural History 225. 